Portland State University

PDXScholar

\title{
Tribal constructs and kinship realities : individual and family organization on the Grand Ronde Reservation from 1856
}

Aeron Teverbaugh

Portland State University

Follow this and additional works at: https://pdxscholar.library.pdx.edu/open_access_etds

Part of the Family, Life Course, and Society Commons, Indigenous Studies Commons, and the Social and Cultural Anthropology Commons

Let us know how access to this document benefits you.

\section{Recommended Citation}

Teverbaugh, Aeron, "Tribal constructs and kinship realities : individual and family organization on the Grand Ronde Reservation from 1856" (2000). Dissertations and Theses. Paper 3237.

https://doi.org/10.15760/etd.3229

This Thesis is brought to you for free and open access. It has been accepted for inclusion in Dissertations and Theses by an authorized administrator of PDXScholar. Please contact us if we can make this document more accessible: pdxscholar@pdx.edu. 


\section{THESIS APPROVAL}

The abstract and thesis of Aeron Teverbaugh for the Master of Arts in

Anthropology were presented August 14,2000, and accepted by the thesis committee and the department.

COMMITTEE APPROVALS:

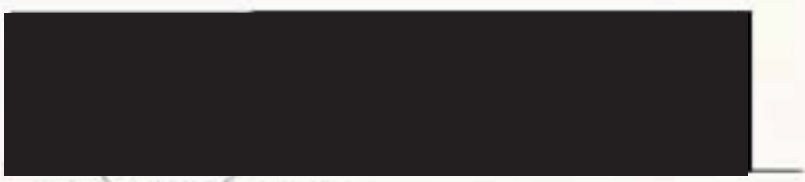

Tom Biolsi, Chair

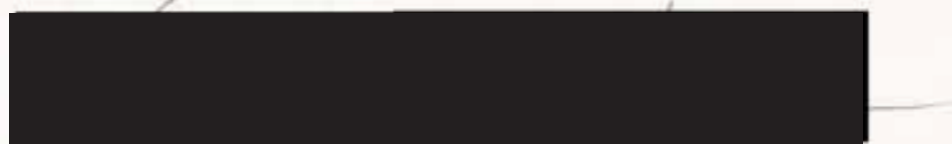

Kenneth Ames

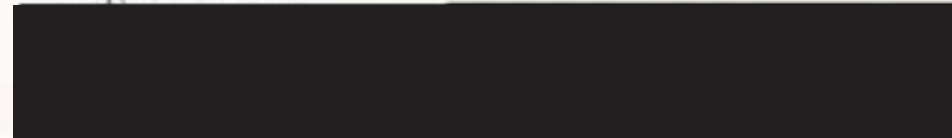

Craig Wollner

Representative of the Office of Graduate Studies

DEPARTMENT APPROVAL:

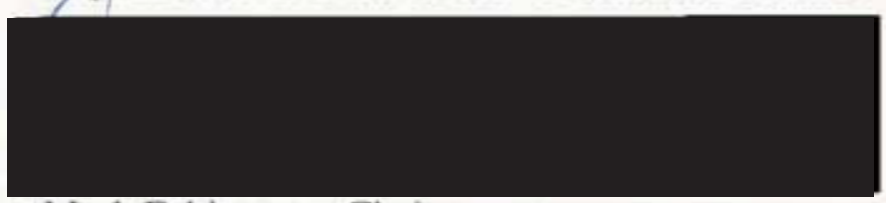

Mark Feldesman, Chair

Department of Anthropology 


\begin{abstract}
An abstract of the thesis of Aeron Teverbaugh for the Master of Arts in Anthropology presented August 14,2000.
\end{abstract}

Title: Tribal Constructs and Kinship Realities: Individual and Family Organization on the Grand Ronde Reservation from 1856.

This project examines marriage and residence patterns on the Grand Ronde Reservation between 1856 and the early 1900s. It demonstrates that indigenous cultural patterns continued despite a colonial imagination that refused to see them. Members of the Confederated Tribes of the Grand Ronde continued to live in family groups much as they had in the pre-reservation era. They continued to exhibit patterns of marriage and kinship that were described in the ethnographies and by the earliest explorers in the Oregon area.

This project is also a critique of the concept of "tribe". Attempts to describe distinct "tribes" in the Pacific Northwest culture area have consistently failed to adequately capture the complex relationships that existed in the area. Due to the importance of trade and exchange among the indigenous population of Oregon, complex networks of kin were created and maintained through patterns of residency, marriage and visiting. Each of these contributed to the native peoples' overall sense of identity. Relations on the Grande Ronde Reservation continued to be sustained through marriage, residency and visiting despite colonial policies of 
forced culture change. The case of the Grand Ronde illustrates that "tribal"

identities are White fictions, and that, at least among the Grand Ronde, family and place were the major components of indigenous identity, not "tribe". 
TRIBAL CONSTRUCTS AND KINSHIP REALITIES:

INDIVIDUAL AND FAMILY ORGANIZATION ON THE GRAND RONDE RESERVATION FROM 1856

by

AERON TEVERBAUGH

A thesis submitted in partial fulfillment of the requirements for the degree of

MASTER OF ARTS

in

ANTHROPOLOGY

Portland State University

2000 


\section{ACKNOWLEDGEMENTS}

Though mine is the only name on the title page, this thesis would not exist without the assistance of a great many people. First and foremost, I need to thank June Olson, the head of the Cultural Resource Protection Program at the Confederated Tribes of the Grand Ronde Community (CTGR). She conceived this project and I can only hope that it does not disappoint her. She gave me a chance as a summer intern, and provided guidance in an entirely new field of research. She suggested the topic and provided me with most of the data I needed to carry it out. She has inspired me to do everything in my power to protect cultural resources of every sort because they are irreplaceable. Ultimately, it was June who gave me a chance to do something useful and valuable. I cannot thank her enough for all she has done for me.

I also owe a debt of gratitude to Lindy Trolan at the Cultural Resource Protection Program. She befriended me and taught me about cultural resources and what I could do. Without her I would not have found the confidence to go for it. I have often said I was extremely lucky to have such supportive people in my life. Tony Johnson, the head of Grand Ronde's language program, provided me with information on the Chinook, told me stories, and gave me things to ponder. Connie Cash, the Anthropology Departmental Goddess, provided everything from laughter to paperclips to office space. If she does not get thanked in every thesis that comes out of this department, she should be. 
I need to thank Trish Rainey for emotional, editorial, and intellectual support. If this project is intelligible it is largely thanks to her editing. Chris Dermody also kindly waded through more information than he really cared about to help me edit and organize. I suppose I should also thank him for being my husband, and an amazingly supportive one at that. My mother, Kate Barauski, also "talked me down" on numerous occasions.

The professors in the anthropology department have been exceedingly helpful to me. In particular I need to thank Dr. Michele Gamburd for helping me combat passive voice, strengthen my research design, and for the use of her storage office. Dr. Kenneth Ames was kind enough to sit on my committee. I am afraid he will never know how important that was to me. Dr. Ames also helped me to direct my research in some very fruitful directions, and his comments have helped me to refine my ideas and rationale.

I owe special thanks to my Chair Dr. Tom Biolsi. Without his mentoring I would not have found my niche in Anthropology; without his fieldtrip I would not have received an internship that steered me down this path; without his support I would not have been able to complete this project.

I also need to thank Dr. Craig Wollner for sitting on my committee. June Olson also took time out of her busy schedule to sit on my committee and give me valuable feedback. Thanks also to Joyce Justice at the National Archives, for all her help finding stuff. I am sure that there are a number of other people that I owe a debt of gratitude to, but in the interest of brevity I hope it suffices to say, "they 
know who they are". Though the thesis itself is the combined effort of lots of people I alone am responsible for any errors that may appear. 


\section{Table of Contents}

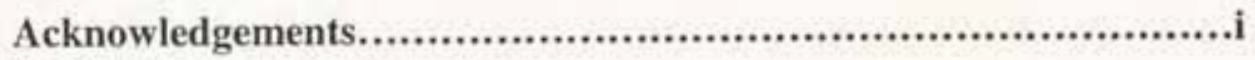

List of Figures.....................................................................

I. Introduction...............................................................

II. Theoretical Considerations..............................................5

Structuring Structures Predisposed to Structure...............5

Making "chiefs" and finding "tribes".......................

The structure and "tribe" ...................................14

Nature and limitations of the sources.........................17

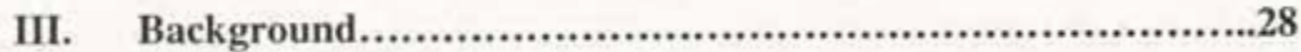

General ecology .........................................28

Bands and tribes............................................. 31

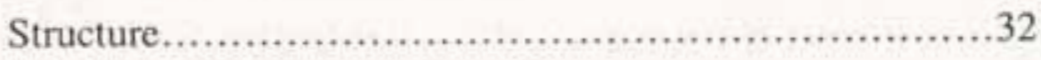

Residency and resources...................................39

Visiting and trade.............................................. 41

New forces on old structures................................49

History of settlement .........................................52

IV. Social Structure on the Reservation.................................60

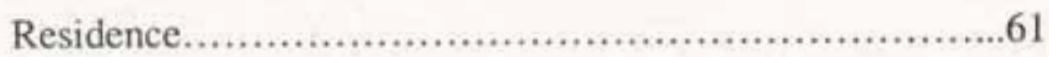

Marriage ....................................................... 79

Other areas of continuity ................................... 87

Identity .................................................. 92

v. Contemporary Social Structure ......................................96

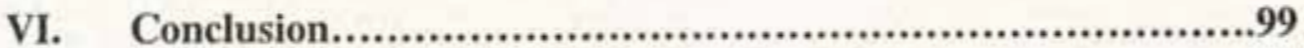

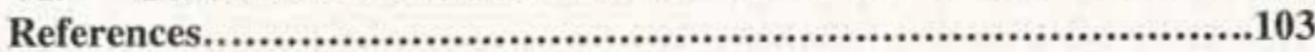




\section{Figures}

Figure 1. Map of Territory under consideration....................29

Figure 2. Band Names........................................ 33

Figure 3. Map of Bands....................................... 34

Figure 4. W.B. Hazen's map of the Grand Ronde..................63

Figure 5. Heartless and Petite Allotments.........................75

Figure 6. Petite and Leno Allotments.............................76

Figure 7. Sangaretta and Holmes Allotments...........................77 
"Audiences know what to expect, and that is all that they are prepared to believe in" Rosencrantz and Gildenstern are Dead

\section{Introduction}

This project is at once ambitious and simple. It seeks to consolidate data from censuses and other archival documents, historic records, and ethnographies into a glimpse of how a sub-section of the indigenous people living between the Cascade and Coastal mountain ranges, dealt with a point in history where "paths" were changed, and an era ended. A severe reduction of population resulting from disease and the encroachment of White settlers permanently altered indigenous peoples' lifeways. However, the indigenous people in the area continued to organize their lives much as they always had. The main organizing factor was family not "tribe' as is often supposed. This project looks specifically at the Confederated Tribes of the Grand Ronde Community of Oregon, which is comprised of several different indigenous Oregon groups. This project seeks to decipher some of the underlying social adaptations that the native population used to maintain continuity with their pre-contact worldview.

This project investigates change and continuity in kinship systems on the Grand Ronde Reservation, from its formation in 1856 , through the early 1900 s. I examine marriage and settlement patterns on the reservation, comparing them to

\footnotetext{
'Tom Stoppard, 1967:84.
} 
early-contact practices ${ }^{2}$. Grand Ronde, like most reservations in Oregon, is a confederation of "tribes". As such, it serves as a test case for an examination of the relative importance of "tribe" membership, as opposed to family membership. Just how important was "tribe" to an individual's conception of identity? If one's "tribal" affiliation was the critically important component to one's construction of "us" and "them", we would expect to find that individual "tribes" would maintain discrete/distinct groups/lives on a confederated reservation. The concept of "tribe" and its relevance to identity was introduced by the colonial situation. It serves mainly to create boundaries that conform to the colonizer's worldview or structural understanding of "how the world works". It seeks to define social relations rather than describe them. Whites created "tribe" as a means of classifying the social structure of indigenous peoples in a way that suited the prejudices and interests of Whites. It is not, at least in many areas of America, how indigenous peoples would have described themselves aboriginally.

The common assumption is that "tribes" were coterminous with cultural, linguistic, and social entities. "The problem of tribe" ${ }^{* 3}$ can be illustrated by showing that individuals on the Grand Ronde reservation organized themselves not in terms of distinct cultural/tribal units, but in other ways, consistent with aboriginal patterns

\footnotetext{
${ }^{2} 1$ use "early-contact" rather than pre-contact, in part, because the lateness of any ethnographic work on the Grand Ronde makes assumptions about pre-contact culture tenuous. See below.

${ }^{3} \mathrm{I}$ borrow, here, the title of the 1967 Annual Spring meeting of the American Ethnological Society.
} 
of organization. This project cannot and does not address the importance of "tribe" to the modern Grand Ronde population in terms of an individual's identity, but it should become apparent that aboriginal cultural patterns underlying perceptions of identity continue.

The methodology and technique I employ for this project fall into the domain of ethnohistory. Hajda defines ethnohistory as the use of historical data and "critical method" in combination with anthropological theory (1984:34). Using ethnographies, genealogies, maps, censuses, allotment records and letters to and from the Indian Agents on the Grand Ronde Reservation, I investigated spatial and kinship relations among and between the residents of the reservation. The benefit of using multiple sources resides in the sources' own ability to "speak" to each other. When the data they contain agree, it tends to be about "facts": time, places, names and so on. Where the records do not agree, we gain insight into the conceptual patterns reflected in the data, hints of underlying worldview.

The paper is formatted in several sections. First, I present the theoretical background, which includes a discussion of the nature of "tribe" as a concept. This section also describes the nature and limitations of the sources used. Second is a background section, which contains information on the pre-contact/early-contact social structures of the people who now make up the Grand Ronde Tribes. This section also discusses the period of Indian-White contact and the formation of the Grand Ronde Reservation in 1856 . The third section addresses early reservation life, 
and contains my findings in regards to patterns of kinship relations on the reservation. The conclusion will briefly discuss contemporary events and how they continue to illustrate elements of an aboriginal worldview and colonial impositions. 


\section{THEORECTICAL CONSIDERATIONS}

\section{STRUCTURING STRUCTURES PREDISPOSED TO STRUCTURE ${ }^{4}$}

By analyzing kinship and residence patterns on the Grand Ronde reservation between 1856 and the early 1900 s and comparing them to pre-reservation life, it became apparent that indigenous lifeways did not die off, but rather, were creatively transformed, by the native people themselves, to meet the new circumstances of reservation life. The new "reality" of the White presence made previous cultural habits of settlement, group structure, and exchange problematic. The native groups adjusted to the new circumstances but within their previous cultural framework.

Perhaps Sahlins (1981) oversimplifies when he describes changes in culture as a result of "failed reproduction". Yet culture, in part, can be described as schematic ways of sorting through and making sense of the world (Douglas 1966). Cultural systems such as marriage and kinship are a "reflection upon order" (Ortner 1994:380). They reflect "the axes of thought, and the limits of the thinkable" (ibid). As we perceive the world we "pre-select and organize" according to our limits of the thinkable (Douglas 1966:37) ${ }^{5}$. Neither the Whites, new to the area, nor the aboriginal people could fully understand the way the other perceived of their world because they had different frameworks through which to filter the material.

\footnotetext{
${ }^{4} \mathrm{I}$ am, of course, taking this from Bourdieu.

"This is similar to, but not exactly, Bourdieu's "doxa".
} 
Cultures obviously must change to meet new historical challenges, so categories of conceptualization must be flexible. In Sahlins' model, change "come[s] about when traditional strategies, which assume traditional patterns of relations....are deployed in relation to novel phenomena... which do not respond to those strategies in traditional ways" (Ortner 1994:399). This change in the context of traditional actions (e.g., drastic population reduction, and shrinking access to former territory) tends to point to a "gap" in the prevailing worldview. The underlying categories will be stretched in an attempt to understand and adapt to the challenges. This in turn affects the categories themselves expanding, limiting, or shifting them. In terms of the indigenous population of Oregon, their perceptions of "how the world works" were expanded to include the new White presence even as their strategies were limited by that presence.

In a colonial situation, the change in context, in part, becomes a change in power relations. We enter into a realm of subjugation and resistance. The colonized are forced, to some extent, to conform to the colonizers' perceptions. But concessions necessary to survival are different than the underlying worldview. This underlying worldview is not static. It changes in response to new stimuli, but changes tend to follow patterns that make sense in light of the existing worldview. In the case of the Grand Ronde, the underlying patterns of perception were acted on to resist new (colonial) categories and played a part in the overall culture change that 
followed. Any discussion about reservation lifeways must necessarily address the power relations inherent in colonization and "naming".

\section{MAKING CHIEFS AND FINDING TRIBES}

Since 1755 , when King George V discouraged colonists from buying land from the Indians, "tribes" have been legally recognized by the Euro-American powers as sovereign nations (Miller 1999). From that point on, relations between Indians and Euro-Americans have been characterized as government-to-government, although on extremely uneven terms. This paradigm was problematic when dealing with the small, loosely knit bands that characterized the Pacific Northwest and other areas. Part of the problem was a lack of boundaries, as well as a lack of centralized authority. The traditional role of the "Chief", in most native polities, was not that of sole decision maker but rather as one well respected among equals (Zenk 1976, Hunn 1990, Strickland 1975, 1992). "Chiefs" did not hold "formal" power over the people in their group but were "informally" quite powerful ${ }^{6}$. Government-togovernment relations however, required that distinct boundaries be delineated for Native American groups, with a recognizable structure of authority akin to a monarchy, oligarchy, or forms (cognitive patterns), which the western imagination

\footnotetext{
${ }^{6}$ Healers or "medicine men" also held a great deal of informal power. They were reduced to the realm of "priests" and then "quacks" by the colonial power.
} 
could understand. This requirement created "chiefs" and "tribes" as we understand them today.

Contemporary scholars in the social sciences (for the most part) recognize the concept of "tribe" as one that colonizers imposed upon Native Americans (Pommersheim 1995, Riding In 1992). Fried (1969) notes that even "tribus", the root of the word "tribe", is plagued by ambiguity; "tribes" have never been easy to describe. Anthropology's recognition that colonialism in fact constructed many supposedly "inherent categories", not necessarily reflective of indigenous conceptions, further problematizes the concept of "tribe"". In many cases, the number of definitions put forward for "tribe" has brought the problem of "tribe" into the open (Campisi 1991).

Anthropology has tried to make "tribe" conform to linguistic groups, to "cultural boundaries" together for mutual defense (Fried 1968). None of these definitions suffice, and as they are melded together in an attempt at accuracy, the definition only expands to its former unuseful state. Linguistic definitions of "tribe" rely on language differences corresponding to cultural and political structures (Fried 1968, Hymes 1968). Language use, however, is contextual, not absolute (Gumperz 1968); therefore,

\footnotetext{
${ }^{7}$ The process of defining "tribes" is akin to the British redefinition of the caste structure in India.

"Cultural boundaries are designates according to similarities in "cultural" strategies like dress, status markers, myths and myriad other criteria.
} 
linguistic boundaries are contextual (Hymes 1968). Hymes (1968) levels a number of critiques against the use of linguistic differences to define "tribe". He points out that different aspects of culture may be passed on non-verbally or in a different language ${ }^{9}$. In addition, multilingual cultures and "code switching"10 complicate the notion of discrete language boundaries.

Hajda (1984) asserts that language users in the Oregon/Washington region were multilingual. She describes a series of patrilocal villages (some more intimately connected than others) each with its own "father language" (Hajda 1984:14). Hajda states that in such a system, where "in-marrying women" would bring their "father language", and particular cultural practices, into the village of their husbands, any given village would have a number of languages that were spoken regularly. Group boundaries were thus somewhat fluid. Hajda surmises that "with polygny and slavery, it is possible that in some villages speakers of the 'native' language were in the minority" (1984:14), making it appear that a common language did not a group make. This would make a linguistic definition of "tribe" especially problematic for the people we are concerned with.

This type of multi-lingualism does not lend itself to discrete "tribal" groups, particularly when "after generations of frequent inter-marriage among villages with

\footnotetext{
${ }^{9}$ An example of this is the use of Latin as representative of medieval religious culture (Hymes 1968). ${ }^{10}$ This would be a fascinating thing to explore for this region of the country but it is outside the scope of this project. It must suffice us to say that the language one uses is a semi-conscious statement of personal identity (Bakhtin 1981). Codes carry with them inherent "meanings" that serve to index
} 
different native languages, the number of linguistic groups represented in anyone's

ancestry would...be considerable" (ibid.,14), as would the cultural repertoires.

There were two means by which the social region utilized this local diversity. In the first place, though primary identity was local, many people increased their repertoires and became multi-lingual and multi-cultural. Chiefs, especially, or others whose role required extensive dealings with outside places, could be expected to be more multi-cultural and multi-lingual than other people. (ibid.,278; emphasis added)

If "chiefs", the main representatives of distinct political units (in the colonial conception), are multi-cultural and multi-lingual, thus further weakening the linguistic approach to "tribe". Linguistic boundaries are, at least for this particular region, somewhat arbitrary.

There were, of course, "names" of social clusters and places before the colonial era. Sometimes group names were applied to or used as self-designations for people usually living in a single village or cluster of small villages (Hajda 1984). With the exception of terms for self-designation, however, all the criteria for tribe are "White" (ibid). There is not a reliable correlation between language and "tribe", mostly, because "tribe" is a non-Indian conception. In some cases a dialect became synonymous with everyone who spoke it. Hajda quotes Harrington's 1942 interview's with Mrs. Luscier, a Chinook informant, wherein she stated that related to the context of the situation/conversation (Gumperz 1968). 
"Chinook' used to be just one place until the Whites came and 'spread it all over"” (ibid., 10)" . Hajda noted that, "physical distance (as in 'Shahala,' 'those upriver') and cultural differences (as in 'Kreluit,' 'they are different') were utilized by Indians to differentiate groups - but not, apparently, to class them together" (ibid., 10).

Indigenous conceptions of identity did not include a person as a member of a discrete "tribal" unit.

In their journals, Lewis and Clark referred to Indian "nations" and to "making chiefs" (Thwaites 1969 3: 208). They classified people in terms of "habits, customs, manners, dress" (ibid). "They, however, like others who dealt in the Northwest, failed to find here the "tribes" of the sort they had encountered further east" (Hajda 1984:9). Even later, reservation era informants had a great deal of difficulty "answering the apparently simple question, to what tribe or tribelet do they belong" (Hajda 1984:11). Therefore, the White imagination did its best to fit local structures into those with which it was more familiar with. Cressman (1981) discusses this phenomenon of creating "tribes" and "chiefs" among the Klamath. The Klamath are a linguistic group, but when "the United States government established its authority in the area, it wanted to deal with men of political power" (Cressman 1981: 63). Because these did not exist among the Klamath, "government representatives appointed "chiefs" of the several groups of villages and dealt with them as though

\footnotetext{
"An explanation of and justification for my heavy reliance on Hajda's Chinook material is presented in the section entitled "Nature and Limitations of the Sources".
} 
they represented the Indians" (ibid.,64). "Chiefs" were emphasized in the records because "other than the Chief, his relatives, and his followers, the social composition of a village is nowhere alluded to in the early sources, let alone described" (Hajda $1984: 165)^{12}$. "Tribes" and "chiefs" were reified by the very creation and use of the terms.

Gooding asserts that colonial "legal discourses [have] operated to obscure the reality of historical relations" (1994:1191). Therefore, the political becomes entangled with our romantic perceptions of what we think Indian should be, and it obscures the reality of what it is, or has been. Defining "tribe" is beyond the scope of this paper, and for reasons which should become apparent in due course, "tribe" does not really need a new definition. Because "tribe" is now so firmly embedded in two cultural imaginings, it is overly cumbersome to avoid the use of the word entirely. When used in the context of this project, "tribe" is not an empirically verifiable series of traits that cluster together ${ }^{13}$. It is, instead, exactly what popular imagination holds it to be. While this definition is vague, it is appropriate because this is the context in which it was being used in all of the documentation. I use the term "band" to describe a group of people living in close proximity, usually related,

\footnotetext{
${ }^{12}$ Often Whites would make "chiefs" out of those easiest to deal with, not even recognizing indigenous status. Though White conceptions associated men with positions of power, women could also inherit "Chief" status (Frachtenberg 1913).

${ }^{13}$ See Sturtevant and Fried for a debates about the usefulness and accuracy of various definitions of "tribe".
} 
by varying degrees, to a "patriarch", or as they later came to be called, "chief". Over time, the White, and later Indian, imaginations lumped these largely kin based groups into "tribes".

As a colonial concept, "tribe" can do violence to the Native American communities it seeks to describe. One blatant example of this violence manifests in cases where native groups are denied official status as federally recognized tribes because they do not conform to federal/White standards. "Terminated" tribes fighting for restoration also face this problem. How does one conform to an aboriginal structure that never existed? When Congress and the courts use the colonial criteria of tribal identity for an indigenous population, they continue misrepresenting the past and imposing colonial structures. Often, indigenous identity and the government's conception of what a "tribe" should be, conflict (Clifford 1998). In his work concerning the Mashpee Indians, Clifford continually discusses the limitations of the concept of "tribe", as it is applied through the courts, because there is an irresolvable discrepancy between the political understanding of a "tribe" and the reality for Native Americans (Quinn1993, Clifford 1998).

My purpose is not to dispense with the term "tribe", but rather to argue for flexibility in its use. To say that tribes do not exist now would be absurd. Even critics of the concept of "tribe" admit that it has become so important as a legal concept that to do away with the term now would only hurt those it helped to colonize, by robbing them of the rights and benefits that accompany "tribal" status in 
the present (Beinart 1999, Sturtevant 1983). There are over 500 recognized "tribes" in the United States, each of which owe their sovereign status to their classification as tribes by the federal government. In the eyes of the federal government, only groups that qualify as tribes are, by their nature, sovereign. The fact that the conditions necessary to qualify as a "tribe" were set down from "outside" does not change its importance to the contemporary relationship between the Indian Nations and the United States ${ }^{14}$.

\section{THE STRUCTURE AND "TRIBE"}

Having defined what a "tribe" was, the colonizers projected their image of indigenous political structures onto the lives of the people. Everywhere they looked, they saw signs of "tribal" behavior. In conjunction with the assimilation policy, they laid out plans to "civilize" (or colonize) the native population. As Whites projected signs of the decline of "tribal" behavior, they congratulated themselves on eradicating tribalism and instilling a more "civilized" way of living. At the same time, they mourned the loss of the "noble savage" as they "picked up" unfortunate "White" habits. In 1859, Miller, the Indian agent at Grand Ronde, lamented that: they learned some of the arts of civilized life, [but] also acquired those habits of laziness and dissipation which are invariably superinduced whenever the price of labor is inflated above it natural value...I only mention this to show

\footnotetext{
${ }^{14}$ The "conditions" vary depending on whether a group is seeking "tribal" status for the first time or seeking restoration, having once been recognized as a "tribe." Since the conditions are not particularly relevant to this paper, I will forego a discussion of them.
} 
what almost insuperable obstacles we have to contend against inducing these Indians to go to work for themselves for what they believe to be bare subsistence (Miller, annual reports: 431 ).

It can be argued, however, that what was occurring was not simply a shift in how the native people were living their lives (acquiring "civilized" habits or "laziness") but also a cognitive shift in the imaginations of the colonizers. Because they looked for actions that seemed "White" they began to see them. The colonial imagination shifted from seeing bands as "communistic" to seeing, instead, White extended families. But both of these were understood in terms of the colonizers' definitions. "Civilized tribes" were credited with employing White strategies rather than being seen as employing indigenous strategies that only appeared outwardly similar to those Whites could identify with. The colonizers did not or could not conceive of indigenous structures different from their own conceptions. "These Indians have always been peaceably disposed towards the Whites; some of them have settled down permanently on their Lands and manifest a disposition to go to work"(Annual Report 1859:430; emphasis added). The point here is that, even actions that look similar on the surface may reflect very different internal understandings. Even as "tribe" becomes more politically significant, the underlying Indian and White conceptual framework of what "tribe" means may continue to be different. 
"Tribes" were not only originally defined by Whites, but they continue to be maintained as discrete units by White habits and policies. Several of the early reports from the Grand Ronde Reservation note well defined tribal areas, both on maps (Hazen 1856) and in references to "the Molalla area" or "Calapooia ${ }^{15}$ section" of the reservation. Reports from the Indian agents tended to identify discrete "tribes" that in fact did not have well defined boundaries of membership. The Indian agent at Grand Ronde wrote, in 1859, that in "reporting the present condition of the Indians on this reservation it will be necessary on account of their great difference to mention the several tribes separately" (430). So, in addition to the "lumping" that occurred, pushing linguistic, cultural or simply local individuals into "tribes", "tribes" were reinforced as separate entities from one another. This habit of documenting difference tends to obscure relations between individuals and between groups. To discuss tribal organization for the indigenous people of the Pacific Northwest is problematic from its outset. Tribes are not indigenous conceptions and therefore could not have underlay indigenous organization. There are no clear, distinct boundaries between groups of people in this region; rather, networks formed between groups. This network strategy would continue on the reservation as well Thus, "tribes" were created and maintained by overlooking connections between

\footnotetext{
${ }^{15}$ There are an estimated 35 different spellings of Calapooia. When not quoting, I will use the spelling that the Confederated Tribes of Grand Ronde currently use.
} 
individuals simply because Whites could not seem to understand them in any other way.

\section{NATURE AND LIMITATIONS OF THE SOURCES}

A range of sources was used in this project. Ethnographies, censuses, government correspondence and reports, historical accounts, maps, and genealogies each contributed to the overall picture. However, all of these sources have drawbacks. Once we recognize the failings we can, to some degree, compensate for them, realizing that they reflect the cultural categories and biases of those who authored them.

By 1835 , Whites had begun to move into the area, and a series of epidemics drastically reduced the native population. Hajda believes that although the indigenous people retained some of their cultural practices and beliefs "their social system was fractured beyond repair" (1984:46). I rely heavily on Hajda's data though her area of study was the Chinook of the lower Columbia. I rely on her for several reasons. Hajda's methodology is similar to my own. In addition to this the people of the Willamette valley married into, and traded regularly with, the Chinook, and many of the residents on the Grand Ronde Reservation recognize Chinook ancestry. In light of this I do not feel it is unreasonable to extrapolate from Hajda's data. I would, of course, prefer to rely on ethnographic information that directly concerns the indigenous people of the Willamette Valley. However, there is very 
little data concerning them. Zenk's (1976) Contributions to Tualitin Ethnology deals directly with the Calapooia of the Grand Ronde, but is mostly concerned with ethnobotany. Zenk has proved an invaluable source especially his study of Chinook Jargon on the Grand Ronde, but as Hajda's technique and concerns are similar to my own I have found her research to be most applicable.

Hajda sought out patterns in exchange relationships from pre-contact times that carried over into times of contact. She wanted to demonstrate how group identities were, in part, expressed and maintained. She uses ethnographic, archival, and historic records to show networks of exchange in the region, and thus prove that "tribe" and "culture area" are concepts ill-suited to fruitful discussions of Oregon and Washington's indigenous peoples, as they fail "to adequately capture the supralocal social organization" (Hajda 1984:1). Similarly, I am seeking pre-contact/early contact patterns of social and spatial arrangement (as it reflects group identity) that carried over to the reservation era. We have evidence of these patterns in administrative records and ethnographies. Unfortunately, the few early ethnographies (Fractenberg 1911,1913-1914, Gatschets 1877, Drucker 1934, and Jacobs 1928-36,1929, 1945, done on the indigenous peoples of the Willamette Valley "tribes", were all produced after settlement on the reservations. White settlement of Oregon (as we will discuss later) did not begin in earnest until the 1850 s. Shortly thereafter, the native groups were moved onto reservations. In addition to the lateness of the ethnographies, early investigators were primarily 
concerned with recording the languages native to the area before the oldest speakers died. Furthermore, as Hajda (1984) stated in her dissertation, the accounts gathered by Frachtenberg, Gatschets and Jacobs are, for the most part, "memory ethnography", wherein informants were asked to recall lifeways from their, or their parents', youth. Often they recounted stories that were passed down to them. These "memories" are vulnerable to nostalgic forces that may call into question their reliability (ibid).

Hajda restricts her use of these sources in order to avoid projecting "remembered" patterns onto indigenous behavior. She opts to use these sources in her analysis of previous changes in exchange relationships in the region only when they can be verified by other sources (1984:24). In doing this, she hoped to compensate for the limitations of the data. I am not as concerned with the inherent reliability of memory ethnography. Memories, especially those colored by nostalgia, will tend to represent "ideal" forms ${ }^{16}$. I believe these are similar to, if not the same as, the "ideal" forms that operate as the structural categories, which organize individual actions and understandings in the real world (Douglas 1966), and while these change, they do so in a pattern largely dictated by the underlying worldview. Thus, memory ethnography, despite its deficiencies in empirical accuracy, is well

\footnotetext{
${ }^{16}$ This is exactly Hajda's complaint.
} 
suited to an investigation of underlying cultural patterns (understood as ideational), especially because they are unconstrained by the less than ideal world.

There are some potentially useful accounts by early settlers (such as Coues1897, Gibbs 1967 [1854], and Ross 1904 [1849]), and by trappers and ship's crews, the earliest Whites in the area. All of these accounts have issues surrounding their credibility in terms of bias or inconsistencies. Accounts written by colonizers will always, to some extent, be filtered through their own set of cultural categories, and will always, on some level, project the imaginings of the colonizer onto the colonized. The authors of these accounts described "tribes" because they were looking for them and could not imagine natives as anything other than "tribal". Fried (1968) provides an example of this phenomenon in the Spanish classification of the people indigenous to Florida. As the Spanish explorers began looking for high status and low status individuals, they increasingly began to encounter this type of social system. These sources are most useful in their confusion. Where White commentators scratch their head over Indian behaviors as not making sense, or when specific types of actions (such as settlement patterns) are recorded, the disparate categories become visible. This is where the individual, inside the colonial structure, creates "tribe""17.

\footnotetext{
${ }^{17} \mathrm{I}$ do, of course, realize that the individual's actions and conceptions can not be entirely removed from the political framework.
} 
Censuses are part of classificatory systems, and have a history in the colonial construction of "native". For example, Anderson (1991) examined how censuses in British colonies helped to define populations and justify colonial designations (such as "Malay" and "Chinese"). They were used to define populations for governing namely, which people were under the government's domain. Censuses serve to "lump" individuals into neatly described units, regardless of the individual's conception of group. Censuses also reify categories by bureaucratically forcing individuals to pick an identity from a limited number of inadequate categories ${ }^{18}$. They were undeniable part of the creation of "tribe" because individuals were asked to state which "tribe" they belonged to. The censuses taken on the Grand Ronde are demonstrations of the administration's conceptions of indigenous people. The procedure for taking the censuses was to list the "head of the household" and how many people lived in the house ${ }^{19}$. The "tribal" affiliation of the head was then assigned to everyone in the house. The only exception to this occurred when men lived with other men, wherein they were each accorded a tribal status of their own.

Anomalies between the censuses' "tribal" designations and the selfidentification of the witnesses in the "Applegate testimonies" are also instructive. The Applegate Testimonies (named for the interviewer) reflect neither purely

\footnotetext{
${ }^{18}$ See Biolsi 1992 for an example of censuses being used to the advantage of the colonized.

${ }^{19}$ Single or widowed women were listed as heads of households; however, if they shared a house with a married couple the women were listed under the man's tribe, regardless of relation to him. This is, of course, one way that censuses create administrative reality.
} 
governmental nor truly Indian identifications. These testimonies were collected from the residents of the Grand Ronde in order to assess who, exactly, was entitled to funds resulting from the sale of "surplus" reservation land. In accordance with a 1904 act of congress, rolls were to be taken to ascertain all those people who "belonged to" the Grand Ronde reservation. In cases where there was any dispute, statements were taken from various members of the reservation community, so as to verify or disprove a claim. The statements include the interviewee's name, background, and their knowledge of the person in question. The way that people identify themselves in these testimonies differs greatly from the oversimplified classifications on the censuses. Because they were asked to describe themselves, the witnesses were able to give at least a glimpse into who they considered "family", and who they thought was part of the reservation. In their reasonings about why someone did or did not belong, the testimonies give glimpses into a minimum requirement for group membership, not language or "tribe" but residence and relations. I use the testimonies as a means to examine conceptions of who belongs where and to show how White categories present a worldview structurally different from that of Native Americans. The testimonies also reflect internal politics of the residents ${ }^{20}$ in their characterizations of each other.

\footnotetext{
${ }^{20}$ This paper is incapable of addressing this on more than a superficial level. It would be interesting, in light of Hajda's discussion of "action groups" in her network analysis, to look at the relations among the most prominent members of the Grand Ronde.
} 
The politics in matters of representation become even more apparent when a researcher utilizes government or colonial documents. While discrepancies between colonial description and the indigenous reality can be caused by an overt (racist) ethnocentrism or political agenda, this is not necessarily the case. More often, I would suggest, the culprit is the categories of understanding that, in their entirety, make up "culture". Simply put, we are inclined to sort through experiences, our own and others, according to established patterns. We will make the world unconsciously, by the very mechanisms of culture - somehow conform to our understandings. In terms of the sources, this means that they will inevitably contain a "White man's" gloss of the situation.

While worldview will "color" the record, on a more blatantly political level, governmental policies will also have an effect on what gets written down and how it is phrased. Indian agents' jobs relied on their successful implementation of the federal assimilation and civilization policy. Therefore, it would not be in the agent's best interests to report that the residents of a reservation were conducting their lives, as much as possible, in the way they had always lived. In the agents' reports to the Superintendency of Indian Affairs, they painted both rosier and bleaker pictures of the reservation depending upon their motivation. In 1859, John Miller the Indian agent at Grand Ronde, began his third annual report by stating that, before he was agent "everything at that time bore the impress of destitution, ruin and starvation" (Annual Reports 1859). He then describes considerable improvement during his 
administration. In 1864, Amos Harvey, in his first annual report, described the buildings as "much out of repair" and the crops "very light" (1864). Yet, in 1862, Grand Ronde was described as possessing "many advantages which others do not enjoy, and, under the efficient management of Agent Condon, is now in a very prosperous condition, notwithstanding the dilapidated condition into which it had been suffered to relapse" (Annual Reports 1862). The use of the term "relapse" is interesting. It sounds as if the "wards" had "relapsed" into an earlier state. At any rate, the report illustrates how each agent made "progress" that others had somehow been unable to produce. The agents had a vested interest in "showing progress" to their superiors in the Office of Indian Affairs.

During Grant's presidency, administration of the reservations was delegated to various religious orders. Indian agents in Oregon were now appointed by the Methodist Church, rather than by the federal government, to administer the reservations (Schwartz 1997). This added another dimension to the politics of the reservation. Temporary agent S.D. Reinhart wrote in the annual report for 1871 , that Lafollet, the previous agent, had resigned because of the "interference of members of the Methodist Church" (1871:303). There is a similar example of politics in the Methodist administration on the Siletz reservation regarding Joel Palmer. Schwarz (1997) states that "the manner of his [Palmer's] leaving, however, suggests that under the new plan, local denominational politics had more influence than did denominational ideals" (Schwartz 1997:186). Because of these, and other, outside 
issues, descriptions given in governmental documents cannot be taken to represent "fact". They, like censuses and other colonial resources, "speak to" White conceptions and so are valuable for comparisons with indigenous actions in order to piece together patterns of worldview.

Maps too play a part in colonial imaginings of a people (Anderson 1991). They bound territories. They create separate groups of people for each area. Reservations are a tangible example of this. The reservation locates a particular group of people on a particular segment of geography, thereby "bounding" them in that territory. They become a single group of people isolated from all others on the opposite side of the imaginary lines between countries, states or allotments ${ }^{21}$. Allotments and the maps that accompany them bound people even farther. Each person is shown as occupying a particular, geometrical piece of land. The overall impression given (especially on large allotments where neighbors seem farther away) is one of isolated individuals. This is, of course, part of the point behind the allotments: that Native Americans give up their "communistic" lifestyle and embrace the American ideal of individuality. Maps, and allotment maps in particular do, however, show spatial relations between people that can be used in conjunction with other data, such as genealogies, to show how people grouped themselves, and how

\footnotetext{
${ }^{21}$ Allotments will be discussed further below. It should be sufficient to note here that they are individual parcels of land given to Indians on reservations in an attempt to encourage individualism among the Indians.
} 
those groupings reflect indigenous cultural understandings of family (Moore1980). Thus, we can use maps to catch a glimpse at the underlying structure of the cultural patterns.

Genealogies play a pivotal part in this project. June Olson, the founder and Head of the Cultural Resource Protection Program for the Confederated Tribes of Grand Ronde, has spent a great deal of time and energy piecing together information on the residents of the Grand Ronde. Her expertise on Grand Ronde history between the 1800 s through the early 1900 s has been invaluable for tracing family connections. Using all of the above-mentioned sources, she has been successful in tracing most of the original inhabitants of the reservation through successive generations. The main criticism of the genealogies is that the information they contain does not include specific information as to how the individuals categorized "family". They only record births, deaths, marriages, baptisms and so on. However, each of these relate to the underlying conception of groups, and so are useful for comparing patterns of social relations.

Indigenous social structures were almost certainly altered by the epidemics that preceded the first direct White contact (Hajda 1984, Zenk 1976). The drastic reduction in population would inevitably have led to changes in "how things were done". Zenk (1976) laments that it may never be possible to piece together precontact social structures. Perhaps, though, we can identify general patterns. Using what information can be collected from native informants, settlers' descriptions, and 
archaeological data, it is possible to make some generalizations about pre-contact lifeways, the definition of kin, and practices that stemmed from it. Since cultures will tend to adapt to change by fitting new input into their existing cognitive framework, the cultural changes that accompanied the arrival of the first Whites will tend to be similar-if not in nature then in style- to the changes that occurred during the subsequent disruptive episode: the reservation. 


\section{BACKGROUND}

\section{GENERAL ECOLOGY}

The Willamette Valley is a temperate subsection of the Pacific Northwest, generally considered to be bounded on the east and west by the Cascade and Coastal mountains respectively. The valley runs south from the Columbia River to the mountains that connect the Coast and Cascade ranges in the southern part of Oregon (Cressman 1981). Though the majority of the "tribes" that make up the Grand Ronde had their original territory somewhere in this area, the Takelma and Chasta Costa resided south of the Willamette Valley nearer Oregon's border with California. The highlighted area on Map 1 shows the general area that the "tribes" resided in aboriginally.

The indigenous people of the greater Willamette Valley generally lived in small, semi-permanent villages scattered throughout the valleys formed by the numerous rivers in the area (Beckham 1977, Toepel 1985). During the winters, the

indigenous people returned to habitual settlements that formed around rivers. Winter dwellings in the area tended to be rectangular plank houses, although some archaeological evidence of semi-subterranean houses exists in the Valley (Ames and Maschner 1999). Houses usually contained several family groups related through at least one of the males (Hajda 1984, Zenk 1990). As the seasons progressed, these "residential corporate groups" would move toward available resources (Ames and Maschner 1999:147, Zenk 1990). "Camp" and "special use" sites around resource 


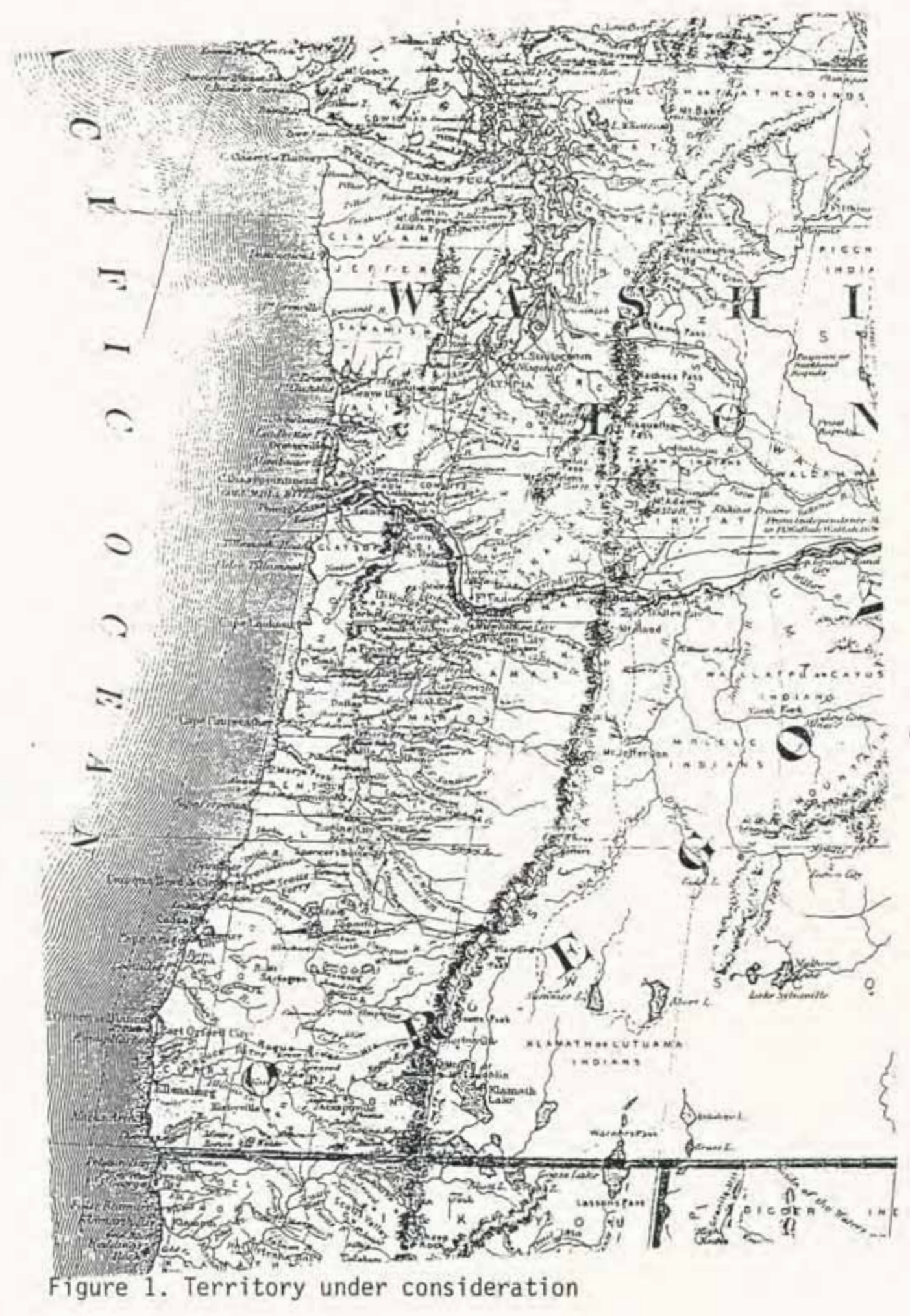


areas dominate the archaeological record, reflecting temporary, task specific movement toward specific resources at specific times (Hunn 1990,Toepel 1985).

Subsistence strategies for the region are usually classified as "broadspectrum foraging" involving seasonal rounds (Hunn 1990). The subsistence techniques of the indigenous people throughout the region overlapped, but with significant differences (Ames and Maschner 1999, Zenk 1976). Throughout the region, fish were used as a resource to differing degrees, game was hunted, roots and berries were gathered. Many of the local groups fished at the falls on the Willamette near Oregon City, collected roots, such as camas and wapato in the prairie land, and hunted elk and deer in the hills. Planned burns throughout the area helped to promote berry growth and in the harvesting of tarweed ${ }^{22}$. All of the "tribes" that make up the Grand Ronde relied to differing degrees on these types of resources. To those inland, hunting preceded fishing in importance ${ }^{23}$; those closer to major salmon runs $^{24}$ and toward the coast relied less on hunting and roots in favor of fish and coastal resources.

\footnotetext{
${ }^{22}$ An added treat was toasted grasshoppers.

${ }^{23}$ The Takelma (Rogue River) Indians lived in mountainous areas and primarily relied on hunting, rather than fishing, and gathering (Schwartz 1997).

${ }^{24}$ The Chinook were reported (by Lewis and Clark and Native informants both) to have "had" most of the best areas to catch Salmon along the Columbia River (Thwaites 1969).
} 


\section{BANDS AND TRIBES}

Identifying discrete tribes in the Willamette Valley is difficult, in part because the difference between a "tribe" and a "band " is not clearly defined ${ }^{25}$. In this area, because indigenous settlements tended to be located on or near rivers, they would be associated, by Whites, with that river. Ironically, this is not very different from one facet of indigenous identity. Traditionally, primary identity was structured around place, usually the village. There were, however, other layers of identity largely indexed by genealogy, which will be discussed shortly. The difficulty with naming "tribes" after rivers was the "White man's" tendency to name a river, and then assign that name to the Indians living in the area. For example, the Mary's River Indians were named after the Mary's River. At its most confusing, we find that members of the "tribe" living along the Calapooia River were called Calapooias. At the same time, the name "Kalapuyan" has been given to the whole group of villages occupying the Calapooia Valley (MacKey 1974: 8).

The ethnographic data presents a picture of villages existing as autonomous units that were connected through ties of marriage and trade, but cannot be defined by those relations alone.

It was almost universally observed that the village, the largest political unit, was not coextensive with cultural or social ties

\footnotetext{
${ }^{25}$ See previous discussion of "Tribe".
} 
such as those created by the widespread practice of intermarriage among villages and groups (Hajda 1984:5).

Some definition of "ideal" groups is necessary, however, because bands and tribes are cited in the literature as existing, and in discrete territories. Though it is oversimplified, and does not address all of the groups in the area, or included in the reservation, Beckham's (1977) list of group names and general locations shows both general habitual territories and the overlap reflective of interrelations between the groups (see figure 1 and map 2). However, in light of our earlier discussion of the difficulty with "tribe" and "band", it must be noted that "the use of group names is...somewhat arbitrary" (Hajda 1984: 11).

\section{STRUCTURE}

Zenk and Hajda both discuss a "moderate social stratification" (Zenk 1976, Hajda 1984). Often, differences in status, among the Chinook, were reflected in how the houses were arranged inside particular villages (Hajda 1984). This may also have been the case among the people in the valley as well. Some areas, including the lower Willamette Valley, differed "from the river mouth and coast in having larger houses, often built attached to form rows, and larger households. These suggest unreported differences in social organization" (Hajda 1984: 264). One observation has been that the larger presumably higher status residences were at the west end of the row of houses because those houses would be more sheltered from some of the 
(figure 1)

\title{
BAND NAME AND TERRITORY OF GROUPS FOUND ON THE GRAND RONDE
}

\author{
Tualatin Tualatin Plains, Wapato Lake, north fork of the Yamhill River \\ Yamhill South fork of the Yamhill River and South to vicinity of Rickreal \\ Creek \\ Champoeg East Bank of the Willamette opposite the mouth of Chehalem Creek \\ Pudding River French Prairie between Pudding River and the Willamette and South \\ to Salem \\ Santiam East side of Willamette between Salem and Albany and east to the \\ base of the Cascades. \\ Luckiamute Valley of Luckiamute River \\ Mary's River Watershed of Mary's River \\ Muddy Creek Watershed of Long Tom River \\ Long Tom Brownsville Area \\ Tsankupi Junction of McKenzie and Willamette Rivers \\ Mohawk Mohawk and Lower McKenzie River \\ Winefelly Lower Middle Fork of the Willamette River \\ Yoncalla Elk and Calapooya Creeks in Umpqua Valley between Oakland and \\ Drain
}

(Beckham 1977: 36)

Also included among the Grand Ronde treaty "tribes":

Takelma Along the Rogue and Upper Umpqua Rivers and their Tributaries (Schwartz 1997:5)

Shasta Along the Illinois River and Bear Creek (ibid.,6)

Umpqua In the Umpqua Valley and on the Cow Creek, a tributary of the South Umpqua (ibid.,10)

Molalla Along the west slopes of the mountains in the Cascade Range on a number of rivers.

See Map \#2 for territories 


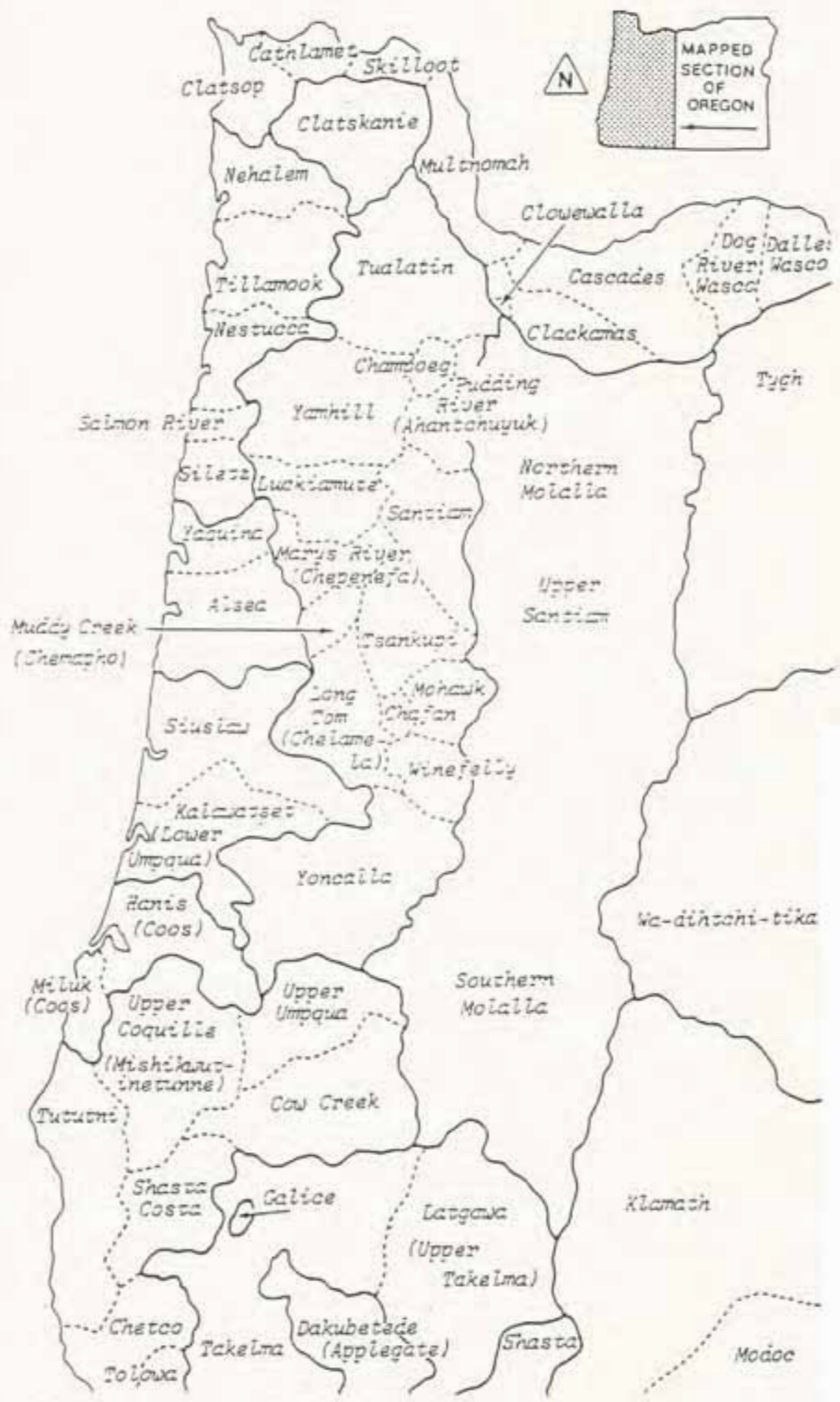

Figure 3. Map of Bands 
wind and thus be warmer. One Chinook explanation told to me was that "all of the good things came from the west".

In keeping with the "west" as the source of valuables, the farther west the bride, the higher her worth. Jacobs' informant, Victoria Howard, states that a child's status was directly related to how much their mother had been "bought" for (Jacobs 1945). For this reason elopements were rare; children from those pairings would have little or no status. Gatschet (1899) also wrote that every child, regardless of sex, gained their status by how much their mother was "worth".

Marriage practices reflect the importance of trade and the creation of networks between groups. Though marriage payments are described as conforming to "bride price", some observers noted that both the groom's family and the bride's family made gifts to each other (Cressman 1981) ${ }^{26}$. In 1934, John Wacheno, a resident of the Grand Ronde, told Philip Drucker that "traditionally" parents arranged marriages and the "principles have to obey" (1934:10). Marriages were arranged to form alliances rather than based on personal preference. This is in keeping with the creation of social ties between groups. The creation of group ties is also maintained by the levirate and sororate. Mrs. Luscier told Verne Ray in 1938 that a chief might take an upper-class widow "if the levirate (going to the husbands brothers, etc.) could not produce a suitable match" (Ray 1938:56-57). Steven

${ }^{26}$ These observers admit, however, that the brides' family came off on the better end of the deal. 
Savage, Albert Gatschet's Molalla informant, stated that a man would "have to marry one's wife's sister. A good man was given that sister free of charge. He could not refuse her. Many wives" (Gatschet 1899: 36-37). All of these practices indicate the importance of creating ties between groups through marriage.

Men of status would seek to expand their influence and alliances through marriage. "Prestigious marriages could increase a chief's rank. While a young ambitious chief's first marriage was likely to be with a woman from a high-ranking, wealthy family, subsequent wives may have been of lower rank" among the Chinook (Hajda 1984:180). Because of the extensive contact between the Chinook and the groups of the Willamette Valley this practice may have occurred in the valley as well. A man with relatively low status might be able to purchase a wife from a "better" family and live in the wife's community with a higher status than he would be accorded patrilocally (Hajda 1984). There did not appear to be any stigma attached to this practice, although this would be impossible to prove. In any case, high status women required larger marriage payments. Only important families usually had the resources to marry into other important families. Those who could afford to "purchase" several wives would do so. Men would marry women from other areas, often women who did not even speak their language, so as to create wide reaching ties (Beckham 1977, Hajda 1984). 
Wealth also permitted polygamy ${ }^{27}$, which resulted in an over-all larger family. A person born into a family wealthy enough to be polygamous would have more half and full sibling $\mathrm{s}^{28}$. They would probably also have more aunts, uncles, and cousins because it is likely that their parents also came from a household with high enough status to afford polygamy; thus, the wealthy would have the widest reaching networks (Hajda 1984:177). These networks were crucial for trade. An early settler in the area noted in 1824 , that a wife would be sent to trade with her relatives on her husband's behalf, and that "marriages were undertaken to 'strengthen commercial relations' - presumably, to promote trade with groups among whom one found wives" (Hajda 1984:130). This arrangement would allow for a wider and more profitable series of alliances than "poorer" families could afford. Marriage set up a continuing series of exchanges of food and other goods, between wive's and husbands' families. These were not "tribal" ties they were familial ones.

Kinship ties formed the basis for connections between individual villages. "Inter-group ties were created and maintained by exchange of goods, marriages, task groupings for activities...gambling, and temporary alliances" (Hajda 1984:23). It is not surprising, then, that marriage among the Willamette Valley groups was

\footnotetext{
${ }^{27}$ Polygny and polyandry both, appear to have been options.

${ }^{28}$ These are western distinctions; it is questionable that the indigenous population made such distinctions.
} 
exogamous (Jacobs 1945, Gastchets 1899, Frachtenberg 1914). What is not clear, however, is how the "outside" was defined. Since "tribes" were not recognized, it was most likely exogamy outside of the immediate village unit or, perhaps, kin unit. Steven Savage told Gatschet in 1899 only that there was to be "no marriage within family" (Gatschet 1899: 36). The family seems to have been the band or village unit, although, because of the inter-connectedness of the area, there was probably also a way of determining which relatives were too close to be marry-able. Exogamy expanded critical exchange networks, and blurred group boundaries.

Native kinship networks were "highly flexible" (Zenk 1984:94). "Even distantly related or unrelated individuals could be, and often were, brought into close relationships through ties of fictional or putative kinship"(ibid.,95). This statement is somewhat deceptive because, other than terms for the immediate nuclear family, kinship terminologies were not recorded until the late 1800s (Hajda 1984: 177). The nuclear family was in the forefront of the minds of the earliest Whites in the area and so it became the subject of interest. The characterization of "unrelated individuals" does not take into consideration that there may have been another way to look at relations. By the time extended kinship terminologies were documented they had been colored by forty or so years of colonial administration on the reservation (Hajda 1984). Therefore, a great deal of uncertainty surrounds the exact nature of the aboriginal kinship system in the area. 
There are several different types of kinship systems represented in the greater Pacific Northwest culture area. Kinship terminologies in this region are bifurcated, meaning that both parents played a role in one's lineage (Hajda 1984:178). Hajda notes that neighboring Chinook and Salish groups use a generally Hawaiian system (1984:177), which de-emphasizes the nuclear family by referring to generational differences. A person sharing your parent's generation will be referred to by the same term you use to refer to your mother or father, depending on the individual's sex. This system tends to occur in cultures where the nuclear family has little legal significance in terms of access to resources or inheritance. This type of system would make sense for an area, such as the one under investigation, where wideranging kin networks are valued particularly in terms of access to resources.

\section{RESIDENCY AND RESOURCES}

Zenk (1974) discovered that different "ownership" patterns existed for different types of resources. Areas where tarweed grew were sectioned off into "village" owned plots, while fishing places were generally communal, frequented by several culturally and linguistically different groups (Zenk 1976) ${ }^{29}$. Gatschet's Molalla informant noted that these areas were not usually considered exclusive but

\footnotetext{
${ }^{29} \mathrm{I}$ am curious if the method of gathering tarweed had any bearing on patches being village "owned". Tarweed was most often burned for ease of harvesting. This procedure would seem to favor ownership by a particular group in order to avoid complications.
} 
that sometimes disputes could arise (1899). Hajda cites the model proposed by Allen Richardson who found that areas of greatest abundance usually had the least regulated/restricted access to resources, resulting in a pattern of village control rather than kin-group control. Kin-group control tended to occur in areas of fewer resources, while individual control surfaced in areas of extreme scarcity (Hajda 1984: 173-174). For the Willamette Valley, then, it is not surprising that we find few resource sites that were individually owned and inherited.

The bifurcated nature of kinship terminologies in the area suggests that patrilineal extended families may not always have been the rule, that women inherited some rights to resource areas, and that, at times, group relationships were structured around women (Hajda 1984).

The winter villages and households were patrilocal in theory. To the extent that theory was practiced, summer residents would be found where people related through women lived - a sister, daughter, mother's brother or father, father's sister. The themes related to a degree. (Hajda 1984: 172)

It appears then, that women would inherit rights to particular places where they gathered, and men would inherit customary places to fish and hunt. Though winter villages were structured around men, summer subsistence groups and tasks centered around women and their root gathering (Hajda 1984). Access to these resource patches may have been part of what the "bride price" covered (Zenk 1976). The pattern of bilateral inheritance was disrupted by reservation life but, as I will discuss later, it continued to structure personal and group identity. 
Schwartz (1997) characterizes the Takelma (or Rogue River Indians) as strictly patrilineal, which would set them apart from the other groups that make up the Grand Ronde. Two reasons could account for this: first, the Rogue River people are from an area further south than most of the groups who found themselves on the reservation. Their subsistence strategies tended to rely more heavily on hunting than on gathering (Schwartz 1997). Another alternative is that Schwartz may be overlooking "female" resources. In light of this, I do not think it is unfair to discuss the Takelma with the other "tribes" on the Grand Ronde in terms of a bi-lateral pattern of inheritance.

Hajda found a possible correlation between marriage ties between groups and connections between those groups' resource collecting sites (1984: 130). Patterns of inheritance and patterns of visiting both reveal and reflect the importance of maintaining distant relationships, in part for the purpose of collecting resources. These practices also de-emphasize group boundaries.

\section{VISITING AND TRADE}

A number of sources describe the foot-trails that crisscrossed the area (Summers 1877). These well worn trails, some of which are still preserved today, speak volumes about the importance of traveling for trade or simply visiting (although it is likely that some sort of exchange occurred during these visits). Through extended visits, resources could be collected and relationships created and 
affirmed (Hajda 1984). Hajda cites Thelma Adamson's “Upper Chehalis Notes” stating that a child would sometimes stay with non-local relatives "for an extended period of time"(1984: 177).

Hajda asserts that much of the 'visiting' mentioned in the sources is related to the collection of resources (Hajda 1984: 175-176). William Clark wrote in his journals that the relatives of the people at Neerchokioo went to Sauvie's Island in the fall and spring to gather wapato and hunt deer (Thwaites 1969 4:225-226). Hajda cites Mrs. Luscier's comment to John Harrington that she dug Oregon Grape roots when visiting a cousin at Rochester, Washington, as an indication of the connection between resources and relatives (Hajda 1984: 176). This practice of visiting becomes part of the problem of classifying "tribes" by linguistic groups or cultural habits. Children staying with relatives in other areas for long periods would pick up new language and cultural practices. These "multi-cultural" skills would be invaluable for creating and maintaining exchange relationships (Hajda 1984). In fact, Hajda suggests that greater cultural repertoires allowed people to travel more widely and expand their rights to resource areas. Between inheritance patterns and the extensive kin ties created through blood and marriage "a man - particularly if wealthy - might have rights in a number of places which could be exercised by moving to one of them" (Hajda 1984:169-170).

A great deal of trade occurred on the river during the winter, together with visiting, and also apart from it; it was an important part of the social relations of the 
area (Hajda 1984: 228). During the winter of $1805-1806$, Lewis and Clark repeatedly observed Indians "in canoes loaded with goods going on trading expeditions" (Hajda 1984:228). Dentalia shells from British Columbia could serve as a type of currency ${ }^{30}$. Among some groups, such as the Calapooia, trade was important enough that "men tattooed their arms with marks to measure lengths of dentalia shells and strings of shells" so that they would always be able to instantly gauge the value of a strand (Hajda 1984:231). The ethnographic record cites many occasions for exchange: "at a shaman's first dance, at a baby's first naming, or perhaps at a girl's puberty ceremony witnesses would likely have been paid in valuables and would participate in a feast" (Hajda 1984:248, also MacKey 1974, Jacobs 1945). Apart from, but very much connected to, kin based exchange systems, there were larger trade centers just as important to the creation and maintenance of the Willamette Valley social structures.

A number of sources mention the "great local center... at the falls of the Willamette", now the site of Oregon City (Clarke 1905). Celilo Falls and The Dalles are also listed as meeting places for both interior and coastal people (Sapir and Sapir 1929). Several such bazaars existed in the region. People came to trade for camas, fish, meat, baskets and even buffalo hide robes from the plains (Hajda 1984, Bowden 1995, Strong 1959). These were also places to socialize, places where "all the

\footnotetext{
${ }^{30}$ Slaves could also be used as currency.
} 
Indians throughout the surrounding country assemble, gamble, and gormandize" (Woodward 1974:174). In the early 1800 s, Alexander Ross estimated the number of people at the falls on the Willamette during fair season at around 3,000 people, while the population the rest of the year was only about 100 (Strong 1959). Different groups brought different resources to the fairs. Jacobs' Santiam informant stated that the Calapooia concentrated on camas while " all the Molalla people did was hunt" (Zenk 1976: 36). Victoria Howard, Jacobs' Clackamas informant, reminisced that the Clackamas would sell a "mashed fish powder" to "foreign groups" who came to the falls (Jacobs 1958: 51). These "markets" acted to expand spheres of interaction beyond local (Oregon/Washington) family ties to British Columbia, California and the Plains, creating exchange relations that reached much further than the Pacific Northwest. Particular locations were associated with particular products, such as Sauvie's Island and wapato, Oak Point and sturgeon, Tillamook and whale products. This "may also have affirmed village or group identity and the relations and ranking among villages or groups" (Hajda 1984:255). Trade and exchange, then, are critical to the relationships between groups.

Inter-group communication at these gathering was aided by the multi-lingual nature of the groups. The Chinook Jargon, the language of commerce in the area, also aided communication ${ }^{31}$. Zenk (1984) has argued persuasively that Chinook

\footnotetext{
"It has also been referred to as a language of romance. Tony Johnson, Grand Ronde's Language specialist, noted at a cultural heritage seminar (July 16, 1999) that since there were several different
} 
Jargon arose aboriginally as a response to the extensive trade that went on in the area, and there is evidence of the Jargon in the journals of Lewis and Clark (Thwaites 1969). Early observers remarked that it was "the language spoken by all the tribes from the rapids to the ocean" (Cox 157: 255). Jargon became even more important during the reservation era when rapid depopulation caused by epidemics and White incursions fractured many of the previous multi-linguistic connections formed in earlier periods through intermarriage. By the 1900 's, "it was definitely the mother tongue of many Indians on the western Oregon reservations: there are people alive today whose first language was Jargon" (Hajda 1984:60). Though I cannot confirm it, one woman I spoke to on the Grand Ronde reservation stated that women in particular would go out of their way to learn Jargon so that they would be included in the excursions to the "markets", thus allowing them to build up trade relations of their $\mathrm{own}^{32}$.

The gatherings were also a time to test one's spirit power through competition and games of chance. People could test their luck against a large number of others and gain status that would be recognized outside the confines of their own group. It served to connect numerous people from wide ranging groups. It brought people together and connected them through debt and/or esteem. Alexander

linguistic groups on the reservation many times the only language a husband and wife would share would be Jargon.

${ }^{32}$ She also noted that it "got them out of the house"; they were not stuck doing chores but could socialize. 
Ross, an early trapper in the area, stated that the people who gathered at the markets were there "chiefly for gambling and speculation, not in fish, but in other articles" (Strong 1959: 44-45). The importance of gambling to the social structure of the Willamette Valley groups is illustrated in the number of times it is referenced in historical, ethnographic and archival sources. Louis Labonte, a member of the Grand Ronde Tribes, recalled watching young men of various "tribes" dive off the bluffs around Champoeg and vie "to see who could remain the longest under water" (Lyman 1900:175). Informants recall watching races at particular gatherings or playing the stick game. Hall (1981) also notes that hunts would, on occasion, be celebrated with large feasts in which a number of groups would participate and play games such as shinny, ${ }^{33}$ or Waitugtug (women's shinny) around which betting would occur. This "competitive spirit" is also addressed in the reports to the superintendency when the agent noted that at school, girls "learn to sew and knit readily... and show a laudable emulation to surpass each other in doing their work well"(Annual Reports 1864:92). Kathryn Gabriel (1996) argues that gambling was a demonstration of spirit power and that one could gain status through that demonstration. Several accounts of Indian gambling concentrate on how much would be lost, up to, and including, wives. This behavior becomes understandable when gambling is put into the context of status. By demonstrating a strong spirit

\footnotetext{
${ }^{33}$ Hall describes it as similar to hockey - adapting it to our cognitive categories (1981).
} 
power, ergo winning, an individual would gain status. If an individual did not win it would have been difficult to simply stop as this would be an admission of weak spirit power and would directly effect that individual's status (Gabriel 1996). This behavior also makes sense in light of the exchange networks that were maintained. Even if a person lost everything, all they really lost was status. The relationships an individual had, to the village or to several villages, would ensure that they would be provided for. A system of "give-aways" required by those with high status (similar to a potlatch) redistributed resources to the rest of the group. Thus, even gambling is intimately tied to the social system of kinship, status, and identity.

In addition to items like obsidian, salt, fish and meat, slaves were also traded. Zenk (1984) states that there were three social strata: "good people" ("Chiefs" and others with high status), regular people (probably distantly related to the "chiefs"), and slaves. Most of the groups in the area had some connection to slavery either by virtue of participating in the capturing, owning and trading, or as the captured, owned and traded. Slaves had no social standing; they were property. A slave could buy their freedom (especially if they gained slave status through debt); slaves could be freed by their owners, or slavery could be a hereditary position inherited by a slave's children. Many slaves who were not debt slaves were captured as children and grew up in culturally alien circumstances. Some members of the chiefly families brought slaves with them to the Grand Ronde Reservation in the 1850s. In the Applegate testimonies a few witnesses state that they had slaves but 
did not trade them for fear of upsetting the agent ${ }^{34}$. Despite their lack of status, slaves and their children were accepted as people who belonged on the Grand Ronde Reservation. One's relation to the groups was gauged by more than just kinship, and certainly by more than "tribe". Slaves were allowed to marry and have families, but they were occasionally killed to mark the passing of their high status owners.

Mortuary customs varied greatly throughout the region. Many early commentators in the Willamette valley wrote that each village would have a corresponding cemetery (Beckham 1977). However, this was not always the rule. The Chinook would lay their dead in a canoe or wooden box to be placed in the branches of trees or on scaffolding (Jacobs 1945). The Calapooia would often use mounds for burials. Sometimes on the Columbia River "islands of the dead" were set aside and deceased persons would be taken out to them (Thwaites 1969, 3).

Practices concerning the disposition of goods after death, among most of the "tribes" that make up the Grand Ronde, seem to be fairly consistent. The sources record that most of the dead person's belongings were disposed of (including, in some cases, slaves) either by sending them with the deceased or giving them away (Beckham 1977, Hajda 1984). Indian agents described this process on the reservation as a freefor-all, where people simply came in and took what they wanted. It is much more likely that there existed a structure governing who was entitled to what.

\footnotetext{
${ }^{34}$ Slavery hit a boom time when the trappers first arrived in the west, but by the mid 1800 s the debate about slavery was heating up and Grand Ronde residents knew that the agents disapproved of the
} 
The young men might take objects associated with the guardian spirits of the dead Indian deep into the forest. The family then burned the bed and blankets and might even burn down the plank house. Often relatives of a dead person abandoned the house for a while or tore it apart and rebuilt it somewhere else in the village (Beckham 1977: 92).

What seemed to Whites to be a destruction of property probably acted to strengthen

group ties by redistributing the deceased's belongings ${ }^{35}$. The White characterization of the native mortuary practices is structured by a White worldview that emphasizes individuality and the nuclear family. It could not adjust to see a system that would aid in the maintenance of wider networks.

\section{NEW FORCES ON OLD STRUCTURES}

Whites, upon their arrival in Oregon, were also incorporated into the structure of trade and competition. "By 1830 it appears that exchange relations of all kinds with Whites, and to some extent with other Indians, were becoming a major basis for the formation of social ties" (Hajda 1984:274). Whites became potential allies. Although trade relations, as we have discussed, had always been important among the indigenous people, Whites added a new dimension. In fact, success in competition for White trading partners may have become a way to increase rank (Hajda 1984).

practice. 
Hajda (1984)states that patterns of increasing status through marriage began to be reflected in regards to Indian-White relations as "Chiefs" began marrying off their daughters to the new Whites in the area. "Alliances with White traders were clearly valued. Three daughters of Clatsop chief Coboway married White men, and possibly four of Concomly's did so" (Hajda 194: 202). "[T]n spite of their feelings of cultural superiority, Chinookans along the river seemed to have been anxious to create any ties that would encourage exchange" (Beckham 1977:158). Whites were seen as having a great deal of valuable resources. Aboriginally marriage into a group gave one access to the resources of that group; marrying into the White community would, therefore, open up access to White resources. Some men tried (although few were successful) to take White wives. These actions are most clearly understandable in terms of seeking high status alliances and opening up (or hoping to) access to new resources. By the 1830 s, Whites became important enough in the trade structure that Chief Casino and his people moved to within ten miles of $\mathrm{Ft}$. Vancouver, probably for the commercial advantages of being close to a trading post (Beckham 1977). White presence, then, did not radically alter the indigenous trade and network building strategies. Whites were simply incorporated into the existing system.

With the Whites, however, came epidemics, which did have a huge impact on the lives and social structures of the indigenous populations. William Clark reported

\footnotetext{
${ }^{35}$ There are undoubtedly issues of worldview and cosmic structure that underlie mortuary customs. This project can not address them, however.
} 
that "small pox has destroyed a great number of the natives in this quarter"(Beckham 1977:104). Early visitors to the area found the ruins of many abandoned villages.

Lewis and Clark estimated that small pox must have taken its toll approximately five years prior to their visit in 1805-06 (Thwaites 1959). In 1830, five years after the establishment of Ft. Vancouver, a malaria epidemic struck. According to Dr. John McLoughlin, mortality in the lower Willamette region and surrounding areas for the native people was perhaps as high as 90 percent (Beckham1977), and "Sauvie's Island had no villages left by 1836" (Beckham 1977: 44). Slacum's "Report on Oregon, 1836-37," suggests that between five and six thousand Indians died along the banks of the Willamette alone (OHQ 13). Before that time, Whites would have been a minority, estimated at no more than two hundred or so compared to perhaps as many as twenty thousand Indians just along the lower Columbia (Beckham 1977).

This drastic reduction of population had an enormous impact on the traditional social structure. The epidemics had "killed thousands of people who had developed the languages, arts, literature, and culture in the valleys and on the shores of Oregon" (Beckham 1977:109).

Traditionally, primary identity was with a particular village, but the population decline resulting from the epidemic quickly led to new groupings of remnant village populations. Indians placed on reservations during the mid-1850s eventually came to accept residence on the reservation as well as membership in a treaty signing 'tribe' as a source of identity. Today it is common to hear Indians identify themselves by the names of their reservations as well as by the earlier affiliations (Hajda 1984:273). 
Though the social system may have been drastically changed by population loss, it appears that the practice of identifying oneself in terms of place had not. The above quotation also reflects the power that White administrative categories such as "tribe" had. Native Americans had no choice but to identify themselves as members of a treaty signing "tribe" if they wanted to be recognized by the colonial system. However, as the passage suggests, individuals recognized themselves in a complex series of contexts. Indeed, "traditional" identity consisted of multiple dimensions "besides identifying oneself with regard to one's present residence, individuals identified themselves by way of their genealogy, including, at least, both of their parents' parents" (Gooding 1994:1209). Zenk (1984) believes that they probably identified themselves (affiliated themselves) differently for different purposes ${ }^{36}$. This layered identity is incompatible with the static "tribes" envisioned by Whites. This multi-faceted identity based on place and family continued on the reservation.

\section{HISTORY OF SETTLEMENT}

A number of archaeological finds suggest at least some sporadic contact between Oregon natives and "White"37 explorers (Ames and Maschner 1999, Beckham 1977). Finds of pottery sake bottles and beeswax suggest that shipwrecks

\footnotetext{
${ }^{36}$ All humans belong to a dazzling array of groups (age groups, socio-economic, task groups, etc.) and index their position in each of them according to the circumstances.

${ }^{37}$ I use "White" as a convenient term that equates to "outside". It should be noted that some of the contacts hypothesized were with Japanese sailors.
} 
on the coast may have been the earliest instances of contact (Beckham 1977).

Documents concerning contact with Oregon's Indians on the coast begin as early as the late 1700 s. Russians and Spaniards both explored the Oregon Coast, but there were no recorded trips to the interior (ibid). In August of 1788, Robert Gray, an American trader, sailed along the Oregon Coast and reported that when he sent a boat to shore "the sailors saw vast numbers of Indians running along the sand waving their elkhide armor" (Beckham 1977: 100). The next day, at the mouth of the Salmon River, a pair of Indians paddled out in a canoe to meet the traders.

'They came very cautiously towards us nor would they come within pistol shot until one of them a very fine look/ing/ [sic] fellow had delivered a long oration accompanying it with the actions and Jestures [sic] that would have graced a European orator.[sic] the subject of his disco[u]rse was designed to inform us they had plenty of Fish and fresh water onshore at their habitations which they seemed to wish us to go and partake of (Beckham 1977:100).

The actions of the Indians in the canoe suggest that they may have had prior contact with less friendly Whites. The author seemed to think that they were familiar with the range of a pistol, indicating that they were probably also familiar with Whites.

The first Whites in the area on a semi-permanent basis (which separates them from explorers and ship's crews) were trappers. The Pacific Fur Company formed in 1810, and by March, 1811, had established Fort Astoria (Beckham 1977). The Pacific Fur Company sold the fort to the North West Company of Canada in 1813, when tensions between American and Britain became strained. In 1821, the Norwest Company (as it came to be called) merged with the Hudson's Bay Company (ibid). 
A few of these early explorers/traders found their way into the Valley. In 1812, the Astorians

pushed for the first time up the Willamette Valley into the lands of the Kalapuya. Later that year, or in the winter of 1813 , they established the first branch trading station in the valley. Eventually, Willamette Post at Champoeg near French Prairie became a permanent depot for these men (Beckham 1977:106) ${ }^{38}$.

By the 1820 s, fur trappers were beginning to invade new areas. They began to participate in trade with the native population, have conflicts, and intermarry.

By 1828 , fur trading in the area was firmly established, and the number of White men in the area had increased. White women, according to the sources, did not enter the area until the 1830 s. "Most of the men stationed at the post took Indian women as at least temporary wives or brought Indian wives from elsewhere and had families and Indian in-laws" (Hajda 1984:266). Some traders and former employees of the fur companies entered into permanent relationships with the groups in the area. They settled on the Willamette, (in spite of policies of sending them out of territory when their term of service ended) in an area that came to be called French Prairie $^{39}$. Many of the family names on the Grand Ronde (i.e. Mercier, Petite, Labonte) attest to French Canadian ancestry. In addition to the French Canadians, a

\footnotetext{
${ }^{38}$ It is interesting to note that Champoeg had been a traditional gathering place for some of the Calapooia people (Lyman 199:175-176).

${ }^{39}$ Because many of the trappers in the area at the time were French Canadians the prairie took its name from them.
} 
number of Iroquois who trapped for the companies came into the area and took local brides. The pattern of creating ties in order to capitalize on a vast exchange network was simply extended to include Whites and others. It was not a matter of linking polities (or "tribes") but of linking individuals and their resources.

Those Whites who came seeking land had a much different relationship with the native population than did the trappers who had settled in the area. The Donation Land Act had an immense impact on the native population of Oregon. When the act was passed in 1850 , there were few Whites in the area aside from trappers, mainly from the trading companies. By the mid 1850 's, scores of settlers had come to Oregon to benefit from the "free land". Of course, much of this land comprised the traditional hunting, fishing and gathering places of the indigenous people. Conflicts arose when Indians sought to collect roots in their accustomed places. In 1851, a White man by the name of Noble claimed a homestead in the Santiam watershed that was the "usual and accustomed" place for the Calapooia to dig for camas. He would not let the Indians come onto his land to collect the roots. The "chief", Black Hawk, made it clear that Noble had a very simple choice; he could allow Black Hawk's people to harvest the roots or he would be removed as an obstacle. Apparently, the ultimatum was successful, and the Indians were allowed to collect camas from the property for some time (Historic Sketch of the Santiam Watershed 1984). The federal government's "solution" to these types of disputes, in Oregon as elsewhere, was to separate the indigenous and White populations as much as possible. The most 
"popular" solution in Oregon was to move the entire indigenous population east of the Cascades (MacKey1974).

Treaty negotiations, to this end, began at Champoeg on April $3^{\text {rd }}, 1851$

(MacKey 1974). They were doomed from the start. The stated purpose of the Champoeg talks was to assemble the

chiefs and principle men of the Kallapooya tribe of Indians at the council house in Champoeg...that they may state their claims to the land they occupy, and that the Commissioners may know the terms upon which they are willing to treat for the purpose of extinguishing their title thereon" (MacKey 1974:88).

However, in February of that same year, Congress abolished all special Indian Commissions, including those who had been sent to Champoeg for the negotiations, and transferred to the Superintendent of Indian Affairs the power to make treaties. Notice of this change reached Oregon about the time that the last of six treaties was concluded (MacKey 1974:129). The negotiators had proceeded in good faith but the promises that were made would not be fulfilled.

Agreements had been reached with several bands of the Calapooia. The negotiators for the United States tried fervently to convince the bands that they should move east of the Cascades. They did not understand that place played a pivotal part in the Indian's conception of identity. The "chiefs" continually replied "that their hearts were upon that piece of land, and they did not wish to leave it...we do not wish to remove" (MacKey 1974:93-94). The federal negotiators asked the "chiefs" if they would share their land with other bands. The "chiefs" agreed that 
was acceptable. Many of those other "bands" would have had relations among the native treaty negotiators' people. The acceptance of bands not included among the groups negotiating the treaties was consistent with indigenous conceptions of belonging. The Indians were once again asked to go across the mountains. They again said no. Once the negotiators for the government accepted that they would not remove, they asked if the "chiefs" would agree to reduce the size of the reserves they had chosen. The Indians had asked for the area between the forks of the Santiam, and the government negotiators were concerned that the Whites living in the area would not leave the lands they had settled (ibid.,94). Finally, in frustration, the Calapooia Chief exclaimed:

We have been willing to throw away the rest of our country, and reserve the land lying between the forks of the Santiam! You thought it was too much, then we agreed to take only half of it, and take in the people South of us, if they were willing. You thought it was too much! Then we agreed to take this small piece between the Creek and North Branch. You want us to still take less, we can't do it, it is too small, it is tying us up in too small a space. (MacKey 1974:96).

The senate never ratified the treaties negotiated at the 1851 meeting at Champoeg. In 1855, a different series of treaties were negotiated, signed, and eventually ratified "with the remnants of a number of groups, mainly in the Willamette Valley" (Hajda 1984:45). Rather than the reserves that the "tribes" had asked for, two other areas were to be set aside that did not place the Indians as close to Whites. 
Joel Palmer became Indian Agent in 1853, and was faced with increasing demands from White settlers that the Indians be removed from the Valley (MacKey 1974). Palmer felt that a section of the coast, not yet settled by Whites, deemed unfit for harbors and therefore undesirable for White use, might be the best reservation for all of the Indians of western Oregon (MacKey 1974:131). So, in the winter of 18541855 , the Indians once again were asked to negotiate their land titles. A series of sessions was held: in Douglas County for the Indians in the Umpqua Valley, at Dayton for the Molallas and Kalapuyans, and one for those Indians residing below the falls at Oregon City (MacKey 1974: 131). Despite more attempts to convince the Oregon "tribes" to relocate as far from White settlement as possible, the local tribes adamantly refused to go; it would have resulted in a great many tribes being relocated into an entirely different environment, leaving behind customary and sacred places. Palmer's plan was not well received. Finally, in return for their lands, representatives of most tribes in the area agreed to settle on one of two reserves that were to be set aside, the Coast Reservation ${ }^{40}$, west of the Coast Range, and Grand Ronde east of the Coast Range. The Grand Ronde, comprised of an area of roughly 60,000 acres, centered on the Yamhill River. A military fort was established on the reservation, Fort Yamhill. The fort was a natural focal point for the local people. Many groups had already begun to camp during the winter near the forts. During the

\footnotetext{
${ }^{40}$ The government drastically reduced the area of this reservation eventually breaking it into two, the Siletz and the Alsea.
} 
series of Indian-White conflicts in 1855-1856, referred to as the "Rogue river wars", many Calapooia bands living in the area made their way to the forts seeking trade opportunities or protection from hostile Whites (Schwartz 1997). Almost all of the interior groups were initially taken to Grand Ronde (Zenk 1976:83). They then dispersed (or were dispersed) to other reservations probably according to where they had relatives (ibid). Over 20 bands from western Oregon and northern California were relocated to the Grand Ronde Reservation. Over half of those relocated to the reservation died during the trip. By 1856 , when the indigenous people began to settle on the reservation they had experienced drastic population loss due to epidemics. They lost many of their elders on the way to the reservation, and they were moving away from their accustomed places. These all impacted traditional social structures, yet, as we will see patterns of behavior and thus the underlying worldview persisted. 


\section{SOCIAL STRUCTURE ON THE RESERVATION}

My premise is that underlying patterns of conceptualization order our world and are reflected in the form of social structures, such as marriage and residency patterns. These concepts, as tools for understanding, and consequently shaping, are "ideal" categories. The reality of social relations is much less tidy. An individual's actions will be framed in the "ideal" understanding of the world but will be constrained day to day by a mundane world ${ }^{41}$. If we argue that culture change is the result of the failed reproduction of an ideal worldview, the underlying assumption must be that social structures, the outward manifestations of our worldview, will change more rapidly than the underlying conceptual categories, which the structures reinforce and replicate ${ }^{42}$. Thus, while in practice the social structures of the native Oregon peoples were necessarily altered to incorporate the reality of White presence, and all that accompanied it, they would still be in accordance with underlying "ideal" conceptions. I have focused on the importance of inter-community ties through marriage. Status strategies, marriage, layered conceptions of identity, access to resources, trade, visiting patterns, and gambling, each rely, to varying degrees, on the creation of inter-group social networks. Each of these practices (again to varying degrees) are visible in the records of the Grand Ronde Reservation. By looking at

\footnotetext{
${ }^{41}$ No plan survives contact with the enemy.

${ }^{42}$ Resistance is also inherent in the reproduction of social categories.
} 
the practices on the reservation, we can see that they follow the structure of previous cultural patterns.

My point is that "tribes" were not part of the aboriginal ideal. Rather, families were. To make this point, I will focus on a few areas of reservation life. I will begin by looking at residence patterns. Looking at the arrangements of the individual land allotments on the Grand Ronde Reservation, it becomes apparent that they reflect aboriginal patterns. Patterns of marriage (in particular, which families intermarried and how that may be related to consideration of status) also illustrate previous habits. Gambling, native doctoring, and mortuary customs, which were documented during the early contact period, also appear on the reservation. Finally, we return to the issue of identity, especially in terms of who "belonged" on the reservation. Each of these facets of social life on Grand Ronde are related to each other; they all reflect the underlying worldview. It is impossible, however, to discuss them in a neat, linear order. Therefore, the order in which these are discussed is somewhat arbitrary.

\section{RESIDENCE}

As discussed earlier, aboriginal settlement patterns for the Willamette Valley tended toward autonomous villages that were inter-related, usually by ties of kinship (which, in turn, created ties of trade and resource collection). The people moving onto the Grand Ronde Reservation in 1856 maintained these patterns. Groups from as far away as the Oregon-California border (the Costa Chasta and Rogue River 
people) found themselves being marched, shipped, and chased onto the Grande Ronde Reservation. The territory that included the reservation was the original homeland of the larger linguistic group classified as Calapooia; most of the other groups were far from their aboriginal homelands. After the groups came to the reservation, they settled in small groups, similar to aboriginal villages, along the Yamhill River. The habit of the resident agent to discuss each "tribe" separately created a bureaucratic tendency to see isolated "tribes". For example: "in reporting the present condition of the Indians on this reservation it will be necessary to mention several tribes separately" (Annual Reports 1859: 430). Hazen's 1857 map of the reservation also charts distinct tribal groupings running along the river (See map 3). Hazen's, and the agents', conception of "tribes" almost certainly led them to describe "tribal" groupings that were undoubtedly better described as bands or families. Zenk produces a similar break up of territories, but states that his informants explicitly commented on "multi-tribal, socially somewhat cohesive and culturally somewhat distinct divisions on the reservation" (1984: 102 emphasis added). These groupings are similar to the patterns of settlement in pre-reservation times, and are definitely not the concrete "tribes" of the White imagination. Though they were described as "tribal" divisions they were probably groups of people related through marriage and blood much as they had always been.

Similarities between residence patterns described in the ethnographies and those described by the agents on the reservation are strikingly similar. In 1873, 


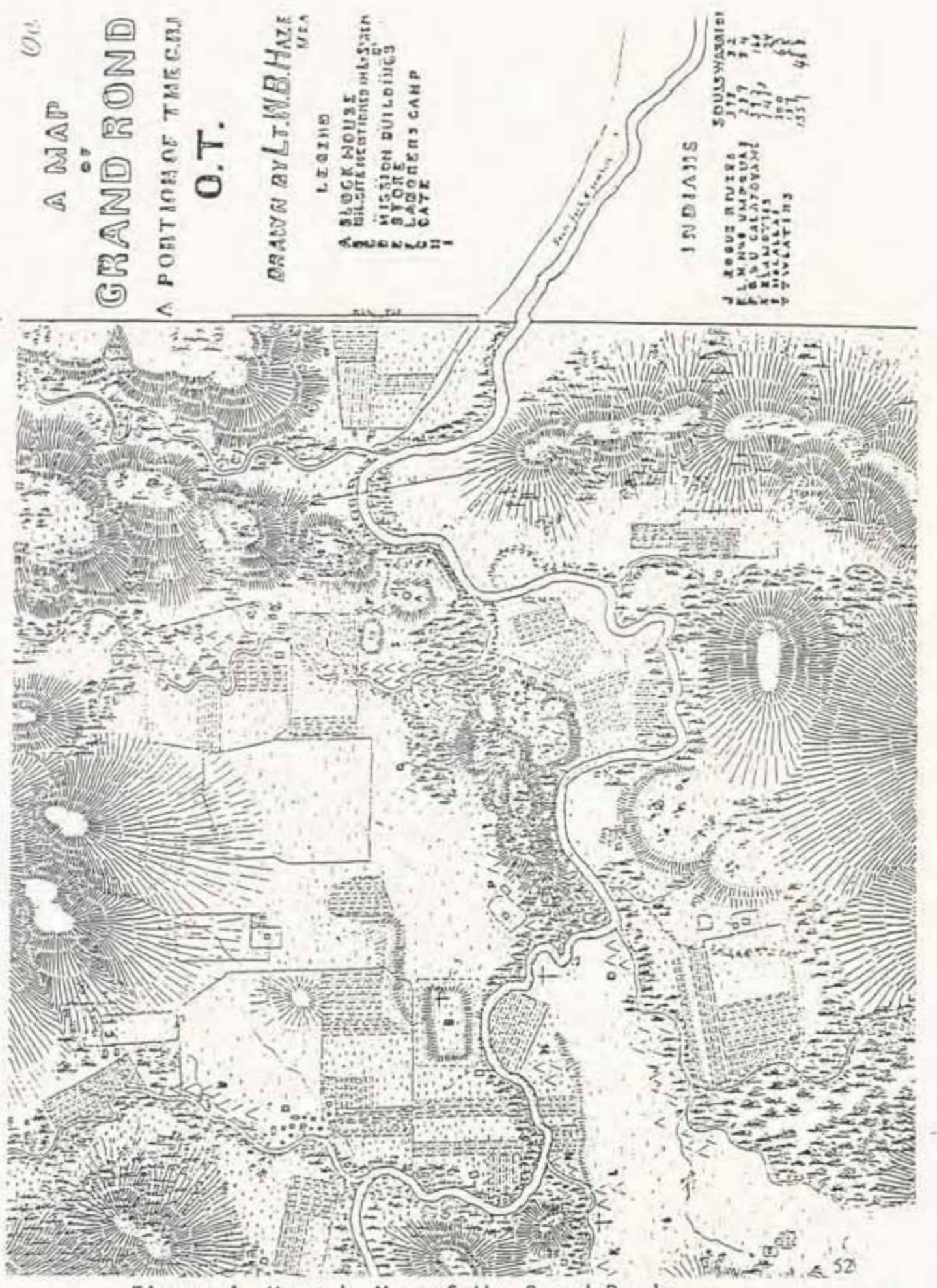

Figure 4. Hazen's Map of the Grand Ronde 
Agent Sinnott wrote "Most of the houses ... have been built in clusters" (1873: 321).

This seems to me to resemble the descriptions of the villages that formed aboriginally. A later report by Sinnott remembered how people had been living when he took over as agent:

I found the Indians living huddled together in families of from ten to fifty...the old the young, married and single, occupying the same apartments, with no restraints upon their actions (1881:142 emphasis added).

This too seems very similar to the descriptions of several families living under a single roof that were recorded by Lewis and Clark for the Columbia "tribes".

Because of the similarities between reservation residence patterns and early-contact patterns, it would appear that they are based on the same underlying structure of "group". I would argue, then, that the make-up of these groups was probably also similar: simply put, that these were not "tribal" groupings as reported, but rather family groupings as recorded in the ethnographies. In other words, members of one residential cluster would likely have had roots in different "tribes" and different linguistic communities. What mattered most for an individual's identity were ties of kinship and location of residence.

One of the reasons there may have appeared to have been "tribal" groups was/is the White tendency to imagine neat patrilineal structures among the groups they encounter. As censuses solidified the "tribes", they also solidified patrilineality. 
The instructions for taking censuses sheds light on how structure on the reservation was changed (at least in the administrator's imaginations) in a particular direction. The bureaucracy structured families in terms of the colonial understanding. The census instructions specified: "Persons to be listed alphabetically by surname in following order: Head, wife, children by age, lastly all other relatives living with them". Each person was assigned to the "tribe" of the "head". This is stunningly illustrated in the case of Sophie Jondreau ${ }^{43}$ and her sister, Larose. The first census that was little more than a head count (meaning it recorded names) was taken in $1872^{44}$. Sophie is recorded as being the wife of Charlie Petite. Her sister Larose lived with them. The genealogies list their mother as "Clackamas Woman", almost certainly denoting a Clackamas Chinook woman, rather than a name. The agent recorded Charlie Petite under the "Oregon City" group along with both Sophie and Larose. No longer was Sophie a member of the Clackamas, as her mother had been, but she and her children, boys and girls, were ascribed to her husband's "tribe". In addition, her sister, simply by virtue of living in the same house with a male ascribed to Oregon City, also became part of the Oregon City "tribe".

\footnotetext{
${ }^{43}$ Persons' names, like place names, seldom had a consistent spelling. Names were recorded according to what the agent heard and could spell. Peter Chekee (or Cheafan, or Chekete) explains: "I told the surveyors that my Indian name was Chafean, but I guess they couldn't pronounce it, so they put it down the way they could spell it and pronounce it themselves" (Applegate Files). I will use the most common spelling for ease of recognition. If in quotes the name is unrecognizable, I will provide the more identifiable spelling as well.

${ }^{44}$ The date given for this census is 1860 ; however, that date does not match with the ages given on later censuses, or other documentation. June Olson and I believe that, based on the ages and birthdates that appear on later censuses, the date of this census was more likely 1872 .
} 
The census instructions went on to define "family":

Family is composed of the following members: 1 . Both parents and their unmarried children, if any, living with them; all other relatives and persons living with the family who do not constitute another family group. 2. Either parent and unmarried children if other parent is dead; all other relatives and persons living with the family who do not constitute another family group. 3 . Single person over twenty one not living with other relative.

Indians were, thus, arranged into patrilineal families. The agents in charge of the census had no choice but to document each Indian in this way; neither their worldview nor the bureaucracy allowed for an indigenous description of family. Discrepancies in worldview are illustrated in the agents' classifications of people "living with family". Sisters, aunts, and mothers-in law were all classified as such, but when the relationship could not be defined in those terms, the notation was simply that they lived with the family. There was obviously some sort of relationship ${ }^{45}$ recognized in these types of arrangements although it defied classification by the agent.

By 1901, a woman's "tribe" would sometimes be documented as different than that of her husband. It would appear that this primarily happened when the woman involved came from a prominent family. Hattie Riggs, Solome Wacheno, and Rosa Wacheno were all descended from chiefs. Mary Metcalf and Margaret

\footnotetext{
${ }^{45}$ It is possible that it reflects "room-mates"; however, it seems likely, based on the importance of kin ties and residency, that these are familial relationships.
} 
Sutton, daughters from wealthy families, were also accorded their own tribe. This probably occurred for the sake of continuity, the agents being aware of the woman's "tribal" designation on earlier censuses, rather than as a recognition of aboriginal practices of tracing lineages through both parents. Despite women beginning to be allowed individual identities away from the tribe of her husband, children were always listed as belonging to the tribe of their father, if he was known and living. Only if the father of the children could not be determined, did they assume the tribe of their mother. I believe that this tendency to associate children with their fathers, and practices of allotment, which will be discussed later, weakened bi-lateral, and matrilineal inheritance structures. Eventually, people would become accustomed to being associated with their father's "tribe" and would respond to the questions of the agents accordingly. It is telling that William Heartless, Jacobs' informant, did 'not remember to whose tribe a child belonged" (1945:38). It may have indicated that he could not understand the question; more likely, it would seem to point at flexible "tribal" boundaries that could not be easily ascribed simply by parental affiliation. Zenk's informant Mrs. Mla (Hudson) Dowd stated that Years ago we always knew we had / so many / different tribes / we never knew which to say if anyone asked what / even now / if someone asked me what tribe / I don't know which to say (1984: $114)^{46}$.

\footnotetext{
${ }^{46}$ Zenk's study is, in part, linguistic. The slashes denote pauses.
} 
The "tribal" designations given on the censuses are usually a number of bands lumped together in accordance with White criteria. Having both man and wife belonging to the same tribe almost certainly glosses over the differences in bands. Considering there were rather strong taboos against endogamy (a practice that makes sense in light of the importance of exchanges), it is highly unlikely that husband and wife were from the same band. Here again, the censuses created "tribes" preferring them to more complex, indigenous notions of identity.

The censuses were, to some degree, consciously creating tribes. The instructions are quite explicit on the importance of tribe.

For each person the following information...Tribe - Care is to be taken that tribe, not band or local name, is given. Thus Ute tribe not Pahvant which is a band of Ute. Likewise do not substitute the location of where the Indian lives for the name of the tribe.

This instruction is interesting on several fronts. First, it recognizes the tendency of the indigenous people to identify themselves as belonging to a particular place. Second, it recognizes the (administratively annoying) tendency of the Indians to identify themselves not by "tribe" but as part of a smaller unit, usually clan/band. These instructions clearly show the colonial classificatory system attempting to dominate indigenous identity; no longer were they part of a band from a particular area, but they were Clackamas or Umpqua, and so on. Furthermore, the tendency to designate families under a single male not only had the effect of over-simplifying the groups represented in a particular house, but it also over-simplified the relationship 
between houses. Thus, rather than seeing a series of inter-connected groups spread over the area, the agents, and soldiers stationed there, saw, and made, distinct, patrilineal "tribal" groups.

Early-contact indigenous groups were flexible. As discussed earlier, people could utilize this group flexibility to increase status. Men of wealth and power could choose to assert their rights to resources in a number of locations. Men of moderate means could "marry-up", live matrilocally, and enjoy higher status at their wife's village (Hajda 1984). Chief Joseph Sangaretta and Chief Louise Nepissank illustrate this group flexibility. Chief Sangaretta was a Long Tom band member. He was adopted into the Marysville (or Mary's River) band and held the position of chief. Chief Nepissank was likewise adopted into the Umpqua band of the Umpqua. Neither group membership nor group leadership were static.

Adoption was not likely a common indigenous practice, simply because it was not necessary. In systems where group membership is flexible and kin ties are very widely ramifying, there would be little need for formal adoption. It is highly likely that if an individual had a connection to a family/village/band, that they could move to that band and capitalize on the kinship relationship that existed. The agents likely introduced the idea of formal adoption, both to tidy up bookkeeping and out of an ignorance of indigenous social systems. During the "Applegate testimonies", in order to ascertain who was eligible to belong to the Grand Ronde Reservation, there are a number of queries about who was adopted into the treaty-signing "tribes". 
Most often, the witness is unsure. With regard to Peter Menard's claim the witness' response indicates that group membership was, in part, achieved through marriage, rather than adoption.

Did you know about Peter Menard being adopted?

No I did not know about him being regularly adopted....then he married a daughter of Chief Joseph Sangaretta. I know that I have heard that Joseph wanted him adopted but whether he was actually adopted or not I do not know.

What about Sam Chantelle?

He was a nephew of Louise Nepissank who came in several years after the treaty and married Anna Amos.... I have heard that Louise wanted him adopted...(Applegate 1905, emphasis added)

In one response, the witness, talking about his own adoption, stated "No, we did not understand that it was necessary." This suggests that "formal" adoption was a foreign addition to indigenous practices. Children were also absorbed in this manner, something that caused no end of stress for the agents.

One of the greatest causes of trouble in the future is the fact that they do not seem to attach any value to their relationship and names. In many cases there are several classes of persons living in the same house, yet belonging to different families. They are in no way related; but they all go under the same name... it is all confusion now, and it is hard to tell how they are related. What will it be in twenty years from now, when all the old inhabitants are gone? In many cases parents die and their children are absorbed into other families and have taken the names of the family that raises them (1859:259).

This passage raises several inter-related issues. The agent's statement that people living in the same house "are in no way related" points to a problem of 
comprehension. He cannot see outside of his "White" notion of family. It may also illustrate that people on the reservation were continuing to identify themselves in terms of their location and "chief". It may be that when people assumed the last name of the person whose house they lived, they were indexing "place" (as in, I live at John's place). It may also indicate a relation between themselves and a patriarch ${ }^{47}$ similar to the relationships that would have existed in the aboriginal, seasonally patrilocal, villages. The connection between names and places is illustrated in Rosie Russie's testimony that Peter Petite and Mary Ann had one child, Henry (Petite) Parr, whose mother "was living with this Parr and he went by this name as he lived with this man and his mother after my husband and she were separated" (Applegate testimonies 1905). Taking the name of the person in whose house one was living would be a temporary identifier, however. June Olson discovered that many people who were "adopted" into families are almost impossible to track when they leave the houses in which they were raised (personal communication). She noted that many of them would take up new names, sometimes those of their parents. This phenomenon points to a continuation of early-contact residence patterns wherein several linked families lived together and identity was negotiated between place and genealogy.

The groupings that occurred on the reservation would, however, be different from pre-epidemic groupings. The devastating mortality rates reduced many villages

\footnotetext{
${ }^{47}$ Patriarch is not quite the appropriate term because of its viricentric connotations, but it is used here as a shorthand.
} 
to only a few members. Remnant villages joined together. Such circumstances were bound to change the relationships between band members; individuals would have to compensate for a loss of relatives. The bonds that had held village bands together had been broken, and the people sought out the next best thing. Originally, land on the Grand Ronde was "parceled out to tribes" thus reinforcing tribal groups (Miller 1857: 367 ). As early as 1859 , agents noted that "during my visit the Indians expressed a very great desire to have the land surveyed and allotted to them in proportion to the size of their families" (Annual Reports: 255).

They manifested a desire to make the allotments themselves - to say how it should be divided, and to whom certain parcels should be assigned...I would urge the speedy surveying of the land embraced in this reservation and the allotting the same to the Indians of the agency in lots of 160 aces to heads of families and 80 acres to single men over twenty-one years of age (Sinnott 1885: 162).

Requests for a surveyor so that the reservation could be allotted reoccur in each annual report by the agents at Grand Ronde. Finally, in 1872 (prior to the Dawes Act) the agent received instructions and urged the speedy implementation of the informal allotting process. "The long prayed for allotment of the lands to the Indians in severalty will be made as soon as the surveys are approved by the department at Washington, to which matter I beg to call your attention and speedy action" (Annual Reports 1872: 303). The agent continues saying that the Indians were "much pleased...many having almost abandoned the hope of getting land"(ibid). The procedure seems to have been that a person would pick a location 
and the Agent would then assign that area to them. Willard Langley testified that his wife, the daughter of Frank Quinelle, stated "the agent told her that if she would select a place he would try to get it for her" (Applegate testimonies 1905).

Allotments on many reservations placed families together so that they could work their land in common. This arrangement was somehow perceived as different than the "communistic" practices of a "tribe" sharing the land, and instead supposedly reflected nuclear family cooperation. When individuals chose the location of their allotment they could place themselves in groups of kin similar to the aboriginal village structure; it also allowed them to choose which relatives they wanted to live by. Allotting individual land only shifted several families living in the same house, or several houses grouped together, to larger more dispersed clusters of families. Regardless of how the practice was understood by the administrators, it resulted in families being arranged together. When the allotment map is examined, we can see that families related by marriage took their allotments next to each other. For example: William Heartless is married the sister of Peter Petite. Figure 2 shows his allotment adjoins Peter's wife, Mary Ann's allotment. Mary Ann's allotment adjoins Peter's. Isabella Petite (Bell Sorenson) has an allotment next to her father's.

Figure 3 shows that Henry Petite, who married Jane, the daughter of David Leno, has an allotment next to David Leno. Also Mary Agnes Leno, daughter of David Leno married Arthur Mercier son of Mary Petite and Francis Mercier. Arthur Mercier has an allotment next to Joseph Leno, Mary Agnes' brother. 
Figure 4 shows Joseph Sangaretta's allotment bounded by Paul Jasper and Luanna Holmes - his grandchildren.

There is a point, of course, where the family relationship breaks down between neighbors simply because of the limited amount of space. The reservation had land suitable for both grazing and farming. If the allottee was a farmer they would need to choose land in a particular area, likewise if they had livestock. Furthermore, the later a family came onto the reservation the less land remained to choose from. Overall, however, the pattern of families living in close proximity to each other seems to hold. Although it is beyond the scope of this report, it would be interesting to discover where the houses were located on these allotments. If family units continued to be important, we might find that each house, while on their own tract of land, was still built close to the houses occupied by relatives. It would be interesting to see how closely settlements on the reservation mimicked earlier village settlements.

It is generally accepted that villages served as the primary unit of political organization in the Pacific Northwest, and the region under investigation in particular (Hajda 1984, Zenk 1984, Ames and Maschner 1999, Beckham 1977). The importance of this unit continued to be illustrated on the reservation. A number of reports by the agent and early observers of the reservation mention the villages that formed along the Yamhill River. These villages were usually interpreted as "tribal" 


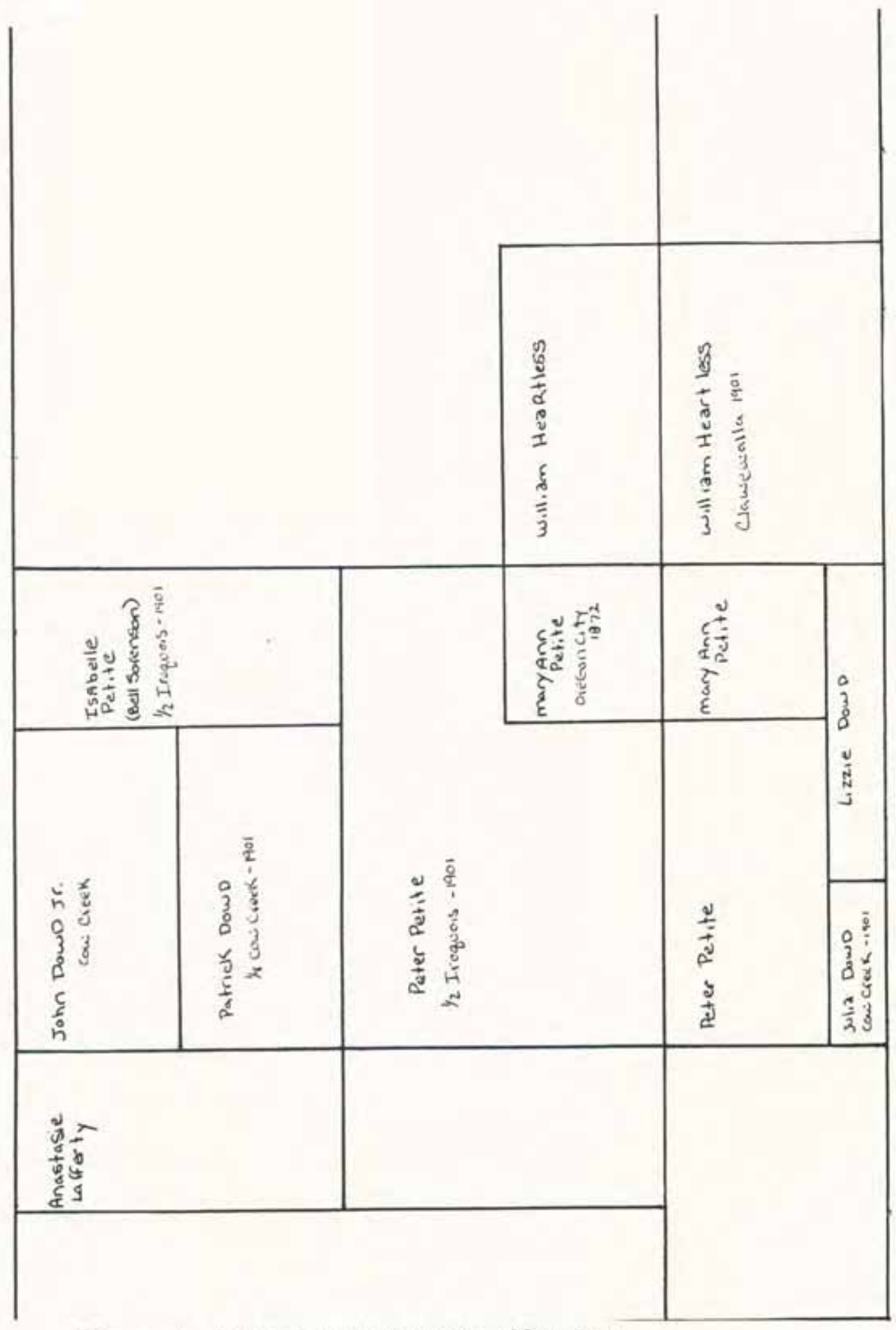

Figure 5. Heartless and Petite Allotment 


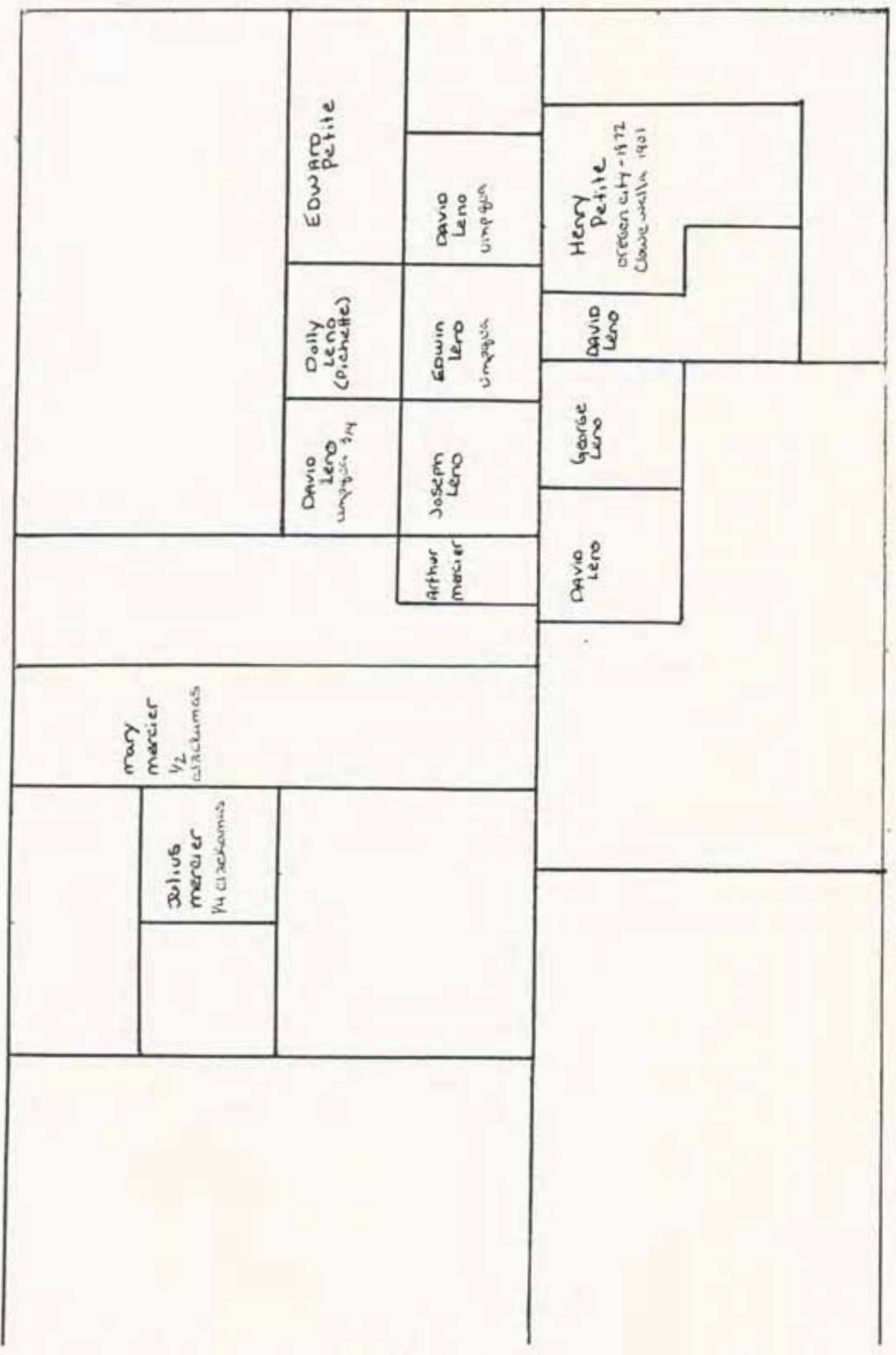

Figure 6. Petite and Leno Allotments 


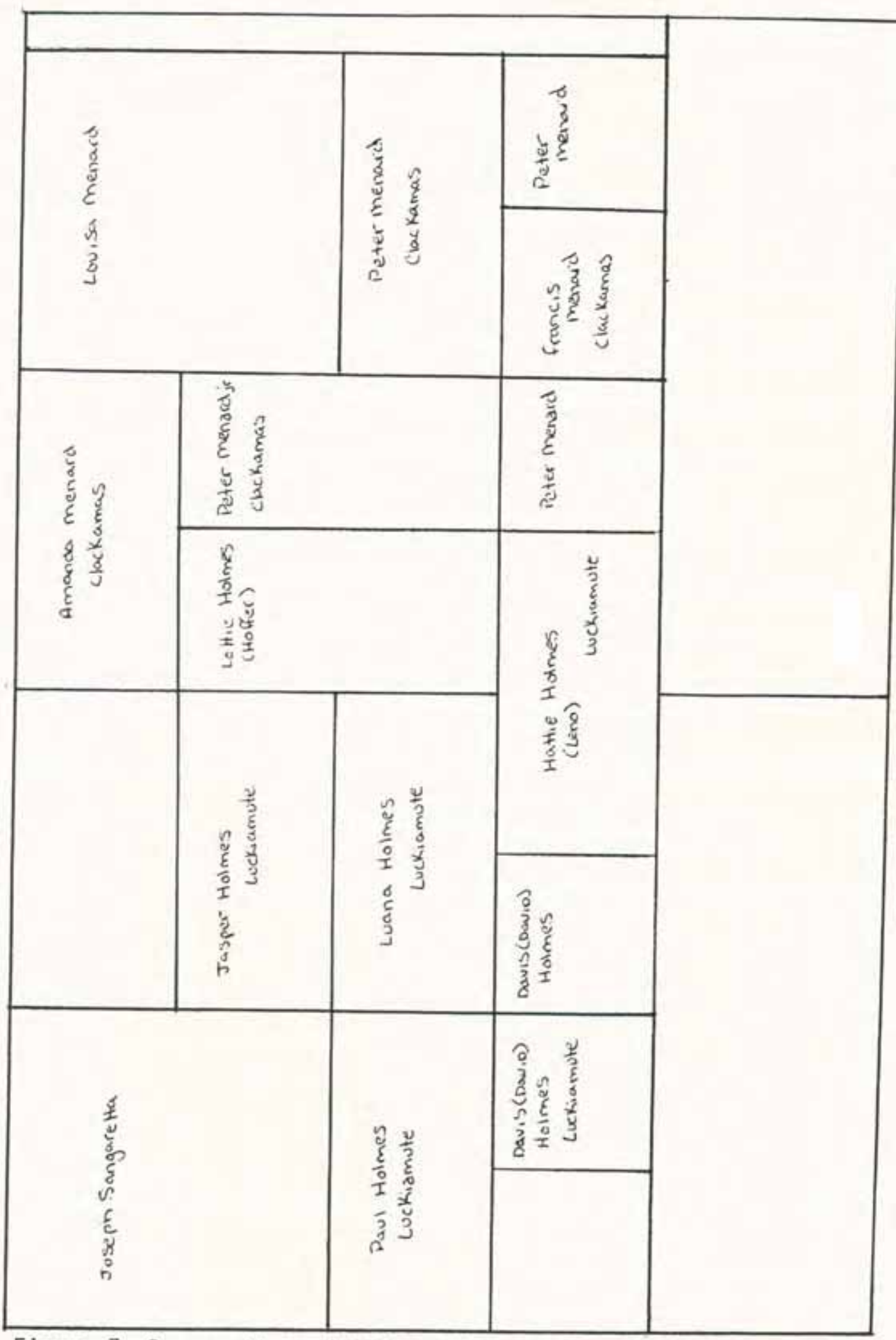

Figure 7. Sangaretta and Holmes Allotments 
units. Representatives were appointed to Grand Ronde's Indian legislation according to "tribe". "Chiefs" became legislators. The division of the reservation into "tribal" groups was abandoned in 1876 in favor of precincts. Rather than electing two representatives for each "tribe", three were chosen for each of the three precincts (East, West and South). Many of the same men that had represented "tribes" now represented the precinct. Between 1876 and 1878 only one new name appears on the list of the governing body ${ }^{48}$. The family names represented in the governing body remain fairly consistent well into the 1880 s. It appears then that "chiefs" and their families continued to hold positions of importance. In addition, the pattern that emerged when the reservation was divided into precincts was very like that of an aboriginal village. Zenk's informant noted the presence of multi-"tribal", socially cohesive groups that closely corresponded to the legislature's boundaries (1984:102). These sections of the reservation were not "tribal" they seem to hold a similar position to aboriginal villages in that they were all connected and yet each remained at least semi-autonomous. Though the groups on the reservation were not autonomous in fact, each group did form a voting bloc. It would appear then, that

\footnotetext{
${ }^{48}$ Included in this are the prestige positions of county commissioner, road supervisor and judge.
} 
despite the changes brought by the colonial administration the tendency toward autonomous villages (comprised of related individuals) remained strong.

\section{MARRIAGE}

Families, not "tribes", continued to be the major organizing force on the Grand Ronde Reservation, as they had been aboriginally. Tendencies of the agents to classify women and children by the "tribe" of the head of the household would make these family groups appear to be "tribal" groups. Giving members of a family allotments in close proximity to each other, in addition to assigning everyone in a family to the father's "tribe", would make it appear as if everyone in a particular spot on the reservation belonged to a single "tribe". Thus, we can see the imposition of White categories on indigenous activities.

Marriage continued to be the primary way of linking people on the reservation as it had been aboriginally. The examples concerning Peter Menard and Sam Chantelle cited earlier describe a situation in which individuals would become part of the group through marriage. In fact, most of the claims in the Applegate testimonies are based on marriage into the group. "What is your wife's name?" "Felineze...she is the daughter of Anna Amos whose mother was the wife of Old Steve Monita who was a Calapooia." Another pattern maintained, was that of individuals with high status marrying into other high status families. According to the genealogies, Chief Peter Selkeah, of the Yamhill Calapooia, married the daughter 
of Chief Solomon Riggs, Chief of the Molalla. Peter Selkeah's son John married the daughter of McCoy who was "second chief of the Umpqua" (Applegate testimonies 1905). John Kawache, Chief of a band of Clackamas ${ }^{49}$, had a son who married another daughter of McCoy's. Bride price continued into at least the early part of the 1900 s (Gatschet 1899). This practice acted much the same way as it had aboriginally; it was mainly men of high status who could marry women from high status families.

As mentioned previously, with the introduction of Whites into Indian Territory, a new dimension was added to high status marriages. Many of the families on the reservation had French Canadian heritage, in addition to Indian. Because it had mostly been "chiefs" that could marry their daughters to Whites, the mixed-blood offspring from those matches had not only Indian high status but also the status associated with Whites. Indians continued to view "Whites" as a means to increasing access to resources. A number of chiefly families continued to create alliances through marriage with Whites. Exogamy remained the rule, but the number of chiefly families that were on the reservation was limited; however, the mixedblood families, though not always descended from "chiefs", had a certain amount of status nonetheless. The status of mixed-bloods is evident in the number of marriages between chiefly families and families with mixed-blood. Chief Joseph Sangaretta's

\footnotetext{
${ }^{49} \mathrm{He}$ was also known as Oregon City John.
} 
daughter, Elizabeth married into the Menard family; his daughter Mary married David Davis Holmes. Alice Wilder, daughter of Chief Sampson Wilder, married Frank Norwest. Frank Quinelle married Larose Nepissank, daughter of the Umpqua Chief. The Petite family has married into the Lenos, the Menards, the Merciers, and the McCoys, all prominent mixed-blood or/and chiefly families. In the cases of Peter Menard and Sam Chantelle, both married the daughters of "chiefs", and the "chiefs" then went to the agent on behalf of their sons-in law, so that they might stay on the reservation. All of these examples point to a continuation of patterns in status and marriage that existed in the pre-reservation era. Those ties created by important families endure today. June Olson has told me that nearly all the current members of the Grand Ronde tribes can trace their ancestry back to at least one "chief", and in most cases two. Zenk (1984) notes that while inter-tribal marriage was the ideal, it was mainly the "chief" who could afford to create the widest ranging ties. Therefore, it is not surprising to see chiefly families maintaining the tradition of "tribe" exogamy.

The introduction of Whites to the area changed more than just status patterns with regards to marriage. It also introduced new ways to achieve status. June Olson found that positions that seemed valuable to Whites, such as road supervisor, agency farmer, carpenter and blacksmith, were all sought out and held by men of prominent families (personal communication). Chief Joseph Sangaretta was the road supervisor in 1876 . In 1877 , the position went to John Wacheno, son of Chief Wacheno, and 
Peter McCoy, son of Chief McCoy. In 1880, Davis Holmes, who had married Chief Sangaretta's daughter held the position. In 1879, three lawyers were licensed for the reservation, each a "chief" or son of a "chief". Joseph Sangaretta also served as a police officer and the reservation's first judge. In 1889, William Warren (related to Winchester Jo, a "chief" of the Umpqua, who held a position in the legislature) was nominated to become the agency carpenter's apprentice. By and large, the new positions that were valued by Whites became valued by Indians. The residents on the reservation could see that with these positions came rewards. Though they were unable to entirely reproduce aboriginal means of attaining status or the benefits reaped from it, they simply incorporated new means and benefits into the traditional patterns of social stratification.

Patterns of status that had been enacted and maintained by indigenous people now had to contend with non-indigenous interference. Agents appointed people to the new positions of status. Because colonial conceptions tended to favor Indians with White blood, considering them to be more "competent", these new status positions were largely closed to full-blood Indians. This caused tensions on the Grand Ronde and led to "half-breed" and "full-blood" factions. Agent Brentano writes, in 1894, "I have found that the Indians are divided into two leading classes. One class is composed of full-blood Indians and the other of the mixed bloods." 50

\footnotetext{
${ }^{{ }^{50}}$ See Biolsi 1992 for a full discussion circumstances leading up to a split between full blood and half breed Indians.
} 
While this tension may have existed since Whites were introduced into Indian families, it seems unlikely considering the indigenous perception of belonging. Aboriginally, one's perception of where one belonged was fluid. Indigenous identity would shift according to the context. The inclusion of Whites did not eradicate that process it simply added another dimension. Even on the reservation one was never simply a half-blood or a full-blood; it was dependant on the situation at the moment. If an individual needed access to the root gathering area of their mother they would likely identify themselves with their mother's village; if on the other hand, they needed access to hunting grounds they would identify themselves by the member of their family ${ }^{51}$ who had rights to that area. Indigenous identity was (and I would argue is) too layered to allow for the confinement of individuals as "either or". It seems more likely that this is another case wherein colonial designations effected the reality for people on the reservation. "Half-breeds" may have appeared to cluster because of the ties of family that organized their placement on the reservation. This may also have had the effect of grouping high status families together on the reservation as they moved near their relatives, making it appear as if the mixed-blood and full-blood Indians were separate groups. Since many of the prominent families were linked through marriage it is not surprising that they would appear to cluster

\footnotetext{
${ }^{51}$ Bearing in mind how broad indigenous understanding of family were, these could be consanguinial, affinal or ficticious relations.
} 
together. Patterns related to status continued despite the new circumstances that surrounded them.

Marriage was still considered important for creating ties between families. Indications of this are found in cases where brothers from one family would marry sisters of another. For example: Arnold and Orville Leno married Maxine and Ramona Knight respectively, and Velma and Martha Hudson married two Mercier brothers, Harold Dean and Hubert. Though this is not technically the levirate or sororate wherein the brother or sister of a deceased will marry the deceased person's spouse, it would serve a similar purpose. Even if the marriage between one of the couples was dissolved the ties that would be created between families would remain through the remaining marriage.

Aboriginally marriage was still considered a flexible tie. This perception did not change despite the Indian agents efforts. In 1891 Agent E.F. Lamson wrote:

A large portion of the heads of families on this reservation are living with their women, married according to Indian custom or by the priest, and I am sorry to say that in neither case is the tie at all sacred, nor does it hold the parties together whenever the man by caprice or because of his fancy to another chooses to sever it. There is, however, a growing disposition to be lawfully married, as I have explained to them the conditions their children would be in towards obtaining their parents' land and other property in the future (1891:371).

The threat the agent used was fairly effective. Children born after the official allotments in 1891 had no way of obtaining land except through inheritance. Indians on the reservation were forced to conform. Though this did not mean that marriages 
had to be any more permanent only that they had to go through official channels to receive divorces before they remarried. Most all of the testimonies given to Applegate make some mention of multiple marriages. Though some couples appeared to remain together for life many individuals married two, three, or four times, according to the genealogies.

It also appears that polygamy was still practiced, despite agency rules. In many cases where a man was listed as having several sequential wives, the birth dates of the children point to polygamy rather than serial monogamy. For example: Joseph Hutchins first married Sarah, who had by him Margaret in 1865, and Sallie in 1870. He then married Margaret Molalla, who had nine children by him, the first in 1859 the last in 1872. Margaret's son Bernard was born the same year as Sarah's daughter, Margaret. Frank Norwest married Rachel who had five children by him: Minnie 1872, Jennie 1874, Josephine 1878, Louis 1880, and Henry in 1883. Spanish Mary, listed as Norwest's second wife also had five children by him starting between 1877 and 1893 . There are at least five other occasions where the birth dates of the children overlap. As discussed earlier, aboriginally, polygamy was favored because it expanded networks of kin. That the practice continued seems to indicate that the underlying indigenous conceptions that favored polygamy remained.

In 1872 , a law was passed on the Grand Ronde that outlawed polygamy, but the practice continued. In 1894, Agent Brentano wrote, "bigamy is very common here. Yet they claim that they are innocent" (1894:259). He laments the poor 
treatment of the wives who are left without any means of support. However, wives left without any means of support was largely the fault of the agents. In the first place, at that time, women had not yet been allotted. Second, it was the law that forced men to choose between wives. Agent Meacham writes that even men who had had two wives for a very long time were forced to give one up. They went to the agent and asked him to choose which woman they should leave; they had lived with both women so long that they were incapable of simply casting one away. Aboriginally, a man would not have to choose between wives. He could support as many as he could afford and if the union was dissolved the woman could simply move to an area where she had family and/or marry again. To people who had always viewed marriages as links between groups, and polygamy as simply a way to expand those links, it was inconceivable to have to sever half of the ties created in favor of the other half.

Polygamy was not a strategy open only to males. "There are also a few cases of polyandry" (Annual Reports 1894: 260). In a letter to the agent at, the Grand Ronde agent explains the expulsion of Coquille Molli from the reservation, for having three or four husbands and announcing her intention to take another. Apparently, Coquille Molli was also unwilling to choose between the alliances she had formed through marriage. This incident occurred after the passage of the law forbidding multiple marriages. It would appear that not even the threat of 
punishment was enough to deter habits based on an indigenous worldview that valued extensive ties, often through plural marriages.

\section{OTHER AREAS OF CONTINUITY}

Marriage and residence patterns reflect continued indigenous strategies indicating a worldview and "Indian" identity distinct from that of Whites or their labels. Other facets of reservation life also show a continued aboriginal understanding of the world. For a while, at least, the custom at death was to give away the belongings of the deceased, much as had been the case in the pre-

reservation era. In 1886, the agent wrote: "another habit among them when I arrived here was, when any one [sic] died that their friends would go and carry off anything they wanted, and leave their families in a destitute condition. They would then move out of the house and either burn or pull down their house" (Annual Reports 1886: 211). This description is almost identical to those contained in the ethnographies; it seems that even twenty-five years of colonial administration did not significantly alter the way the indigenous population regarded death. If aboriginal mortuary practices served, in part, to reaffirm ties by sharing the deceased belongings then the continuation of the practice seems to indicate that these ties remained important on the reservation. Friends and family continued to play their part in redistributing goods at death. Aboriganally, the practice may have served to reinforce ties between families or individuals and families after their direct link - the deceased - had been 
severed. The continuation of the practice may point to the continued importance of the ties.

Indian healing and spirituality, as part of indigenous identity, show a similar tenacity despite agents' claims that it was declining.

Before I came to this reservation.... it was the custom for them to come here from other reservations and have their Indian dances in large houses on the side of the hills, and cover them nearly up with dirt. Two of them remain on the reservation, where they held their powwows for weeks at a time (1886: 210-211).

Jacobs (1945) recorded in his "Kalapuya Texts" that the Warm House Dance (probably the same as the "Earth Lodge Cult") was very popular on the Grand Ronde Reservation. This movement was inspired by the Ghost Dance movement ${ }^{52}$ and received a "very enthusiastic reception at Grand Ronde in 1871" (Beckham 1990:

183). Though many residents had begun to participate in the Methodist and Catholic churches on the reservation, they continued to attach great importance to their indigenous spirituality often melding the two. Agents continued to complain about "superstitiousness" among the residents. In 1886, J.B. McClane, the Indian agent, reported that he had offered \$100 to anyone who would demonstrate (on McClane) the power of killing people with a glance (Annual Reports 1886: 211). The Indians declined, explaining that the power did not work against Whites, just Indians and

\footnotetext{
${ }^{52}$ The Ghost Dance celebrated Indian identity and customs. The movement was spiritual and spoke of a coming age when Whites would return to where they had come from and the Indians would have their land back.
} 
animals. The fact that Whites seemed immune to the powers of the Indian doctors did not destroy the indigenous faith in them, rather they had an explanation ready at hand. The White immunity was removed from the relationship between the Indian doctors and their patients - Whites were simply excluded from the equation. Indian spirituality was maintained at all social strata. McClane was disturbed that one of the individuals who believed in the power of the doctors was a "quite intelligent man, with considerable property" (Annual Reports 1886: 211). Zenk notes that John Wacheno, son of Chief Wacheno, was an ardent "later day" (around the 1920s1930s) supporter of "shamanistic ceremonies" (1984:122). Despite membership in the churches on the reservation, and despite governmental policies condemning acts of indigenous spirituality, the underlying identities, frameworks, and the beliefs they supported, remained intimately tied together.

It also appears as if the actual practices of Indian doctors remained consistent with early-contact forms. Ethnographic descriptions of Indian doctoring note that women healers would tend toward "sucking" remedies. They would use their mouths or a straw to suck out bad blood from the body of their patients. Men would practice other forms of healing that involved dances or spirit animals rather than sucking. The agent's description of a case involving a healer on the Grand Ronde in1886, seems to indicate that the techniques for healing had not changed at all. The agent writes 
A leading Indian had a very sick daughter. The doctor here could not save her. They got an Indian doctor. She undertook to draw the bad blood out of her by sucking the part of the body that was the most affected, and would draw it out in her mouth and spit it out in a basin (Annual Reports 1886: 211).

Healers had traditionally held positions of status. They would often have influence equal to that of the "chiefs". The position of "chief" was not only a recognition of someone's political or financial status, but also of their spiritual status. Jacobs (1945) recorded an example of the connection between "chiefs" and strong spirit power. He collected a story in which two prominent members of the Grand Ronde were ascribed powers:

One man, a shaman (Zangretter- he was part Mary's River Kalapuya), said long long ago when there were many people(Indians) here, he always knew who was going to die." "Now then that person's (Zangretter's) dream powers told him..." "There was one Yamhill man who had strong spirit power... Se'lkya (Peter Selky, husband of Louisa) (Jacobs 1945:70-71).

Both of the men discussed, Joseph Sangaretta and Peter Selkeah were "chiefs". This seems to indicate that aboriginal perceptions of the qualities possessed by men of status continued well into the reservation era. It may also indicate that being a "chief" on the reservation still required a demonstration of strong spiritual strength, consistent with the pre-reservation chiefly requirements. Strong spirit power continued to be valued even under the cover of Christianity.

There continued to be a number of ways to demonstrate spirit power. Gambling remained a popular pastime and way to bring groups together. Agents 
were continually complaining about Indian "facilities for gambling, a habit so strong among all" (Annual Reports 1881:142). In 1886, the agent complained, "I learned that there is some gambling going on; that I have not been able to entirely stop as yet"(Annual Reports 1886:210). Indians on the Grand Ronde continued to negotiate status (and therefore identity) through gambling. Thus, earlier patterns of seeking status through gambling, at the risk of losing all one's belongings, still occurred. In 1888 , the agent wrote that giving money to the Indians would be counter-productive because "they spend it drinking and gambling, and come back to the reservation as poor as they went, if not poorer"(Annual Reports 1888: 205). If this behavior was a result of seeking status according to the aboriginal system, which seems likely, then it is an indication that aboriginal conceptions of how status was gained were not completely replaced by newer, White introduced strategies, but rather that new strategies were simply added to older ones. Aboriginal conceptual categories continued to dictate behavior even though the changed circumstances of reservation life made exact reproduction impossible. "Give-aways" could no longer support those who had lost everything gambling, the aboriginal "safety nets" were gone, the actions became, in some cases, detrimental to the individual, but the actions continued because the underlying worldview had not significantly changed. Gambling continued to be seen as a way to demonstrate spirit power and to gain status. It continued to play a part in the creation of individual and group ties. In short, it continued to play a part in indigenous identity. 


\section{IDENTITY}

All of the above mentioned dimensions of reservation life point to a continuation of pre-reservation practices and, thus, to the aboriginal conceptions that underlie them. All of these examples point, in differing ways, to indigenous forms of making and determining identity. In no place is the conception of identity clearer than in the Applegate testimonies wherein witness were asked to testify as to the identity of themselves and others who asserted they belonged on the reservation. The testimonies illustrate reasons why a person did or did not belong. Testifying for Lucy (Sampson) Lane, Moses Lane testified:

What is her blood and how is she related to the Grande Ronde Indians?

She is a Tillamook Indian and came to Grande Ronde Agency when the Indians came from Tillamook to this agency...Her father who was an Indian doctor, was known as Doctor Sampson... He was a Tillamook and her mother was an Alsea woman whose native country was near the coast...Dr. Sampson often came here to visit and doctor the Indians here...

Did Lucy have relatives here and did she get land here?

Yes she had quite a number of relatives here then and has several here now.

His testimony is interesting on several fronts. It indicates that indigenous medicine men were still making their rounds. It illustrates the connection between the "tribes" in the area, and most significant, Moses Lane's claim for Lucy rests not on the fact, 
that she is a member of a treaty "tribe" but that she has relatives on the reservation. Those relatives are her "right" to access the resources of the area. This would be consistent with aboriginal conceptions. A person belonged on the reservation if they had relatives there who would accept them.

Are you related to Mrs. Mary Voutrin?

Yes she is my aunt, a full sister to my father...I know when she came back though. I think it was in 1881 ...her relatives and friends were anxious to have her come back and live here, they went with her to the agent to ask to have her and her children accepted.

Again, we see that relatives are the key to acceptance. Zenk states that "reservation 'tribefolk', like aboriginal villagers typically regarded each other as relatives" (1984:95). This is not surprising, as the residents of the reservation probably were, to differing degrees, related in the same way that residents of the aboriginal villages had recognized extensive kin networks. Traditionally, these networks structured residence, access to resources, and patterns of visiting and ultimately one's sense of where they belonged, as they continued to do on the reservation.

One particularly intriguing facet of the Applegate testimonies involves a possible connection to previous bi-lateral inheritance patterns. The colonial structure forced the Grand Ronde people into strictly patrilateral patterns (unless the father was unknown). Women were not allotted land on the reservation until 1893. Their traditional gathering places had long been over-run by settlers. Wappato Lake had been turned into pasture-land, and the camas fields were fenced off. Even before 
women arrived on the reservation, they had little property or resource areas left to pass on to their daughters. Agents, by documenting only the father's tribe, robbed women of even their ancestry. However, it may be that the matrilineal mindset still remained. The statement of Elizabeth Menard, in answer to the question of name and ancestry, gives her mother's name first:

My maiden name was Elizabeth Sangaretta, and I am a lower Chinook descendant. My mother's name was Nancy Sangaretta... and who was a daughter of Pisk's first wife a lower Chinook Indian woman...My father was a mixed blood Indian, named Joseph Sangaretta...a Marysville Indian.

In addition to giving her mother's identity first, she refers to herself under her mother's "tribe" - lower Chinook, rather than her father's. Unfortunately, there are few women included in the Applegate testimonies. Not all of them give their mother's tribal name first, but, this could be explained in several ways. These were "official" testimonies, which may have caused informants to give the information that they knew the interviewer was asking for: namely, what tribe would you be classified as, and that was "officially" the father's. It may also be due, in part, to having to choose a single ancestry. Because these testimonies were taken in order to establish who was entitled to funds deriving from the sale of "surplus" lands, it was in the witnesses' best interests to identify themselves with "Indian" blood rather than mixed or White. This flexible identity is consistent with aboriginal patterns wherein a person likely identified themselves differently in different contexts. To utilize the 
vast networks one would likely express the identity most applicable to a given situation. If an individual was seeking resources in a particular area they would play up their ties that gave them a legitimate right to that area. For instance, if a woman's mother was Mary's River Calapooia and her husband was Umpqua and she had cousins in Molalla country, she would likely refer to herself as Mary's River when she was claiming rights to her mother's root gathering areas. She might emphasize her relation to her husband to claim Umpqua resource areas, and her relations to her cousins when visiting Molalla country for resources. This type of flexible identity allowed for full exploitation of the vast social networks, and the members of the Grand Ronde tribes continued to utilize it on the reservation. It indicates that indigenous methods of identification continued. 


\section{CONTEMPORARY SOCIAL STRUCTURE}

We have seen that the continuation of pre-reservation practices on the reservation points to a continuation of early-contact and, therefore, aboriginal ways of acting in the world. Indigenous conceptual categories did not disappear even with the termination and dissolution of the reservation. In 1954, the legal relationship of the Confederated tribes of the Grand Ronde with the federal government was terminated. During this period of federal Indian policy it was deemed too expensive (as well as un-American) to continue to maintain tribes that appeared to be "civilized". In the spirit of assimilation the government cut loose the people of

Grand Ronde $^{53}$. By the 1970 s, termination was deemed a failure and tribes began to petition for restoration. The Grand Ronde were restored by congress under several provisions restricting their rights to self-government (for instance, they are unable to sell timber from the reservation other than domestically until 2006). The wording of their restoration acts created a single confederated identity, simply "The Grand Ronde". Agent Metcalf stated, quite plainly, in 1857, that the reasoning underlying confederation was to "prevent complication of accounts" (Letter to the Superintendency, July 20,1857). So for ease of accounting, "tribes" were formed and then "confederated tribes" administratively altering indigenous identity for the convenience of Whites. But, even after termination and restoration, there are indications of continuity with indigenous understandings visible in the actions of the 
contemporary inhabitants. Though many of these have been tempered by forced culture change and the imposition of White cultural categories, indigenous identity still underlies the new, quite modern understandings.

The native people of Grand Ronde continue to identify themselves in terms of place. As Hajda (1984) discussed, it is not uncommon for members of native communities to identify themselves in terms of the reservation on which they live. In fact, this identification with place has become so powerful that many times a person will be unable to give an accurate "tribal" genealogy. For example, at a meeting with a federal group, the nine tribal council members of the Grand Ronde were asked to cite their names and tribes. A knowledgeable informant noted that a third of the group gave inaccurate information, not to be deceptive, but rather because they were unsure. June Olson believes that Indian identity, at least in terms of the Grand Ronde, is still multi-layered (personal communication). However, outside pressures to simplify identity so as to make it comprehensible to the government, is acting to reduce multi-layered identity as a member of a "tribe" and "band" in favor of an identity based only on place. She told me that for herself, she realizes that when she is asked to what tribe she belongs, her answer will depend on who is asking the question. Most non-Indians are seeking the name of a recognizable place or tribe. To give a band name would only be

\footnotetext{
${ }^{53}$ The devastating effects of the termination of tribes is discussed elsewhere.
} 
overly confusing. There are others, however, who want to know more specific details of family and band, and the response to these queries is more elaborate. This seems to me an excellent example of White practices/desires/needs forming the responses of Native American people. This is not to say that, at some level, internal conceptions are not changed by external factors, but rather, that you cannot gage internal conceptions just by external trappings. 


\section{CONCLUSION}

The preceding analysis demonstrates that we perceive the world in accordance with cultural categories. This tendency both aided in and resisted colonial domination. The White imagination created "tribes" where there existed kin groups. It tried to simplify indigenous social organization and identity by assigning immutable "tribes" to each of the inhabitants. It solidified "tribal" differences by recording them; it created patrilineal descent through the censuses and by not allotting women. It created positions of status and then assigned them to mixedblood persons creating false divisions between residents on the reservation. However, this imagination could not force Indians to see the world through completely White eyes or act in a manner totally inconsistent with their worldview. The people of the Grand Ronde continued to identify themselves in terms of their kin ties. They continued to group together in families, not "tribes". They continued to maintain status distinctions through marriage, and they continued to express their indigenous identity by maintaining their early-contact mortuary and medical practices. They continued to gamble as part of their system of networks and status. In short, the native underlying conceptions of the world continued to manifest in native actions. They conceded points to the colonial administration (such as giving a "tribal" name when they were asked) simply adding another context to an already flexible conception of identity and belonging. They reproduced pre-contact social structures as much as possible. If it was failed reproduction, it was still fairly close. 
All of the preceding analysis leads to one conclusion: outside conceptions of behavior as "White" or "civilized" or as "tribal" are colonial glosses, which do not accurately represent how actions on the part of the colonized, in this case Native Americans, are understood internally. It is exactly in this manner that "tribe" as a legal concept does violence to Indian people. It forces Indians to live up to criteria that may never have existed and refuses to acknowledge patterns which are truly aboriginal. The result is that if native peoples cannot show "indigenous" patterns of behavior according to what the White imagination supposes it to be, they are penalized for not being recognizably "authentic". It is imperative that lawmakers, anthropologists, and Indians alike, realize that it is the underlying categories of conceptualization that structure actions and make them "Indian" or "White". Crosscultural behaviors that may appear similar on the surface will still be colored by those underlying understandings of how the world works. Those understandings may be fundamentally different. Though the tenets of cultural relativism dictate that foreign cultures operate under their own system of logic, it appears that contemporary Native Americans do not receive the same treatment. They are often characterized in terms of the larger American culture or as remnants of extinct or static cultures. These characterizations ignore the vibrant Native American cultures that continue to thrive. It does not allow Native American cultures the potential to change that we seem to recognize in all other cultures. However much time and changing circumstances have altered the outward actions of indigenous people, it is 
unreasonable to ignore cultural continuity. This is not to say that Native Americans are wholly foreign or impenetrable, only that their worldviews should not be characterized by "White" standards; to do so is to be directly implicated in the continuing colonization of indigenous people.

This type of categorization/colonization of indigenous behavior is illustrated in perceptions of Indian casinos. Many critiques have been leveled against reservation casinos, from both inside and outside the Indian community. Frequently, casinos are viewed as Indians "selling out" to a White commercial enterprise. However, the ethnographic and historic records prove that gambling was important aboriginally for the maintenance and extension of networks that directly contributed to indigenous conceptions of identity. Casinos are not a White addition to the reservation but a return to the great gathering places so common in the early-contact era. It can also be argued that the Spirit Mountain Fund, which gives back $5 \%$ of casino profits to Oregon's communities at large, is a type of "give-away" similar to those held by "chiefs" in earlier times. The comparison is not exact, however. The creation of the Spirit Mountain fund was a political and public relations tactic to ease response to the casino, and the sphere of the "give- away" is no longer just the Indian community of the Grand Ronde. In fact, one criticism is that the funds are not usually used for the benefit of those living at Grand Ronde. However, the implementation of local Head Start programs and the annuity checks distributed to the community do have the effect of "giving back" to the people. In addition to this, 
the Tribal Council gains status through the distribution of funds to "worthy" causes, not unlike that gained by "chiefs" during the "give-aways". I am not arguing that modern Indian casinos and tribal councils are the same as the gatherings and "chiefs" of aboriginal life, only that they are most readily understandable as progeny of an aboriginal worldview adapting to new circumstances.

We all look at the world through cultural eyes. White historians will look at changes in history and explain them by looking at the underlying culture. Native Americans, however, are discussed in terms of Euro-American culture rather than their own. It is true that colonization forces changes in behavior; however, wherever there is domination, there is resistance. Residence patterns, marriage patterns and the persistence of other indigenous expressions suggest that underlying Indian conceptions of how the world works continue in the face of colonial impositions. In fact, the power of our underlying conceptions of the world may be such that "breaking" them is impossible. 


\section{Bibliography}

Aikins, Mel

1975 "Archaeological studies in Willamette Valley, Oregon"

Anthropological papers Nov.8, Eugene: University of Oregon.

Ambrose, George

1856 "Journal of Removal of Rogue River Tribe of Indians" (Manuscript 1856-165, micro copy 2 roll 14, Records of the Oregon

Superintendency, in record group 75, National Archives, Washington)

Ames, Kenneth and Herbert Maschner

1999 Peoples of the Northwest Coast: Their Archaeology and Prehistory.

London: Thames and Hudson.

Bakhtin, M.M.

1981 The Dialogic Imagination. Austin: University of Texas Press.

Beals, Herbert

1994 "Gladstone, Oregon, a History (Part One: Earliest Times to the Civil

War's Eve)" Salem :Gladstone Historical Society.

Beckham, Steven Dow

1977 The Indians of West Oregon: This land Was theirs. Coos Bay Oregon:

Arago Books.

1990 "History of the West Since 1846" in Handbook of North American Indians vol. 7. Suttles ed. Washington D.C.: Smithsonian Institution.

Beinart, Peter

1999 "Lost Tribes: Native Americans and Government Anthropologists Feud over Indian Identity" Lingua Franca May/June 9(4): pp.32-41.

Beresford, William

1789 "A voyage Round the World; But More Particularly to the Northwest Coast of America: Performed 1785,1786,1787, and 1788, in the King George and Queen Charlotte" ... London: Printed for J. Stockdale, and G. Goulding. (Reprinted: Biblioteca Australiano No.37, Da Capo press NY 1968) 
Biolsi, T.

1992 Organizing the Lakota: The Political Economy of the New Deal on the Pine Ridge and Rosebud Reservations. Tucson: University of Arizona.

Bourdieu, Pierre

1977 Outline of a Theory of Practice. Austin: University of Texas Press.

Bowden, Bradley

1995-1997 "A new Look at Late Archaic Settlement Patterns in the Upper Willamette Valley" Association of Oregon Archaeologists Occasional Papers \#6 Paul Baxter ed. Contributions to the Archaeology of Oregon. Eugene, Oregon.

Boyd, Robert

1986 "Strategies of Indian Burning in the Willamette Valley" Canadian Journal of Anthropology 5(1). 65-86.

Campisi, Jack

1991 The Mashpee Indians: Tribe on Trial. New York: Syracuse University Press.

Canby, William

1998 American Indian Law In a Nut Shell. St. Paul: West Group Publishing.

Cariton, Robert

1927 History of the Willamette valley Oregon Vol.1. Chicago: The S.J.

Clarke publishing co.

Carrillo Jo ed.

1998 Readings in American Indian Law: Recalling the Rhythm of Survival. Philadelphia: Temple University Press.

Clark, Ella Elizabeth

1953 Indian Legends of the Pacific Northwest. Berkeley: University of California Press.

Clark, Ella ed. 
1955 “George Gibbs' account of Indian Mythology in Oregon and Washington Territories". Oregon Historical Quarterly 56(4) 293-325 and 57(2) $125-167$

Clifford, James

1998 "Identity in Mashpee" in Readings in American Indian Law. Jo Carrillo ed. Pp. 19-26. Philadelphia: Temple University Press.

Collier, Jane Fishburne and Sylvia Junko Yanagisako eds 1987 Gender and Kinship: Essays Toward a Unified Analysis. Stanford: Stanford University Press.

Collins, Lloyd

1951 The Cultural Position of the Kalapuya in the Pacific Northwest (Unpublished MA thesis in Anthropology). Eugene: University of Oregon.

Corning, Howard McKinley

1947 Willamette Landings. Portland: Oregon Historical Society.

Coues, Elliot ed.

1897 "New Light on the History of the Greater Northwest: The Manuscript Journals of Alexander Henry, Fur trader of the Northwest Company and of David Thompson... 1799-1814 ... 3 Vols. New York: Francis P. Harper. (Reprinted: Ross and Haines, Minneapolis, 1965) (2:867)

Cressman, Luther and William Laughlin

1941 " A probable Association of Mammoth and artifacts in the Willamette Valley" American Antiquity 6940:339-342.

Cressman, Luther

1981 The Sandal and the Cave. Corvallis: Oregon State University Press.

Clyman, James ed.

1984 Journal of A Mountain Man . Missoula: Mountain Man Press.

Douglas, David

1953 [1826] "Journal kept by David Douglas during his Travels in North America 1823-1827”. New York: Antiquarian Press LTD.

Douglas, Mary 
1966 Purity and Danger: An Analysis of the Concepts of Pollution and Taboo. London: Ark Paperbacks.

Drucker, Philip

1934 "Clackamas Notes" Bureau of American Ethnology. Smithsonian Institute MS. 4516 (78) vol.6.

Fried, Morton

1968 "On the Concept of 'Tribe' and 'Tribal Society"' in The Problem of Tribe: Proceedings of the 1967 Annual Spring Meeting of the American Ethnological Society. June Helm ed. Pp. 3-20. Seattle; University of Washington Press.

Frachtenberg, Leo

1913 Kalapuyan Ethnology

1914 [1851] Oregon state library Film 32 A, Salem 1915 "Ethnological Researches Among the Kalapuya Indians" Smithsonian miscellaneous collections 65 (6) 85-89

1909 [Hanis Coosan Ethnographic Notes and Myths in English] (Manuscript \#330 in National Anthropological Archives, Smithsonian Institute, Washington)

1910-1911 [notes from Stephen Savage concerning the Molalla] (Manuscript \#2517 pt. in National Anthropological Archives, Smithsonian Institute, Washington).

Franchere, Gabriel

1969 "Journal of A Voyage on the North West Coast of North America During the Years 1811-1814" [1820] W. Kaye Lamb ed. Wessie Tipping Lamb, trans. Toronto: The Champlain Society.

Gabriel, Kathryn

1996 Gambler Way: Indian Gaming in Mythology, History and Archaeology in North America . Boulder: Johnson Books.

Gatschet, Albert

1877a [Atfalati (Kalapuya) Materials] (Manuscript \# 474 in National Anthropological Archives, Smithsonian Institute, Washington)

1877f [Three Texts with Interlineal English Translations from Stephen Savage, Grand Ronde Reservation, Oregon] (Manuscript \#998 in 
National Anthropological Archives, Smithsonian Institute, Washington)

Gooding, Susan

1994 "Place, Race, and Names: Layered Identities in United States v.

Oregon, Confederated Tribes of the Colville Reservation, PlaintiffIntervener" Law and Society Review 28(5): 1181-1229.

Gough, Barry ed.

1992 The Journal of Alexander Henry the Younger 1799-1814. Toronto:

Champlain Society.

Gumperz, John

1986 Language and Social Identity. New York: Cambridge University Press.

Hajda, Yvonne

1984 Regional Social Organization in the Greater Lower Columbia 1792 -

1830. (Dissertation University of Washington). Ann Arbor: University Microfilms International.

Hall, Francis Cushing

1981 Indian Life in the Willamette Valley. Portland; Oregon Historical Society.

Hays, Marjorie

1976 The Land that Kept its Promise (A History of South Lincoln County).

Newport: Lincoln County Historical Society.

Hunn, Eugene

1990 Nch'I-Wana 'The Big River: Mid-Columbia Indians and Their Land.

Seattle: University of Washington Press.

Hymes, Dell

1968 "Linguistic Problems in Defining the Concept of 'Tribe"' in The

Problem of Tribe: Proceedings of the 1967 Annual Spring Meeting of the American Ethnological Society. June Helm ed. Pp. 23-48. Seattle: University of Washington Press.

Jacobs, Melville 
1967 "Our knowledge of Pacific Northwest Coast Indian Folklores" Northwest Folklore 2(2) 14-21.

1945 Kalapuya Texts. Seattle: University of Washington Publications in Anthropology \#11.

Kane, Paul

1859 "Wanderings of an Artist Among the Indians of North America, From Canada to Vancouver's Island and Oregon". London: Longmans, Brown, Green, Longmans, and Roberts. (reprinted C.E. Tuttle, Rutland, VT. 1967).

Keesing, Roger

1975 Kin Groups and Social Structure. New York: Holt Rinehart and Winston, Inc.

Lane, J.

1878 Autobiography (manuscript P-A 43 in Bancroft Library), Berkeley: University of California.

Lee, Daniel and Joseph Frost

1844 Ten Years in Oregon. New York: Published for the authors by J.

Collard. (Reprinted: Ye Galleon Press, Fairfield, Washington, 1968, Arno Press, New York, 1973).

Lyman, H.S.

1900 "Reminiscences of Louis LaBonte" Oregon Historical Quarterly Vol. 1 March. Pp. 167-188

1900 "Indian Names" Oregon historical Quarterly \#1. pp. 316-326

Mackey, Harold

1974 The Kalapuyans: A Sourcebook on the Indians of the Willamette Valley. Salem: Mission Hill Museum Association inc.

McLoughlin, John

1941-1944 "The Letters of John McLaughlin from Fort Vancouver to the Governor and Committee. 3vols. E.E. Rich ed. Toronto: The Champlain Society

1948 "Letters of Dr. John Mclaughlin, Written at Fort Vancouver in 1829. 1832. Burt Barker ed. Portland: Binfords and Mort for the Oregon Historical Society. 
Meares, John

1790 "Voyages Made in the Years 1788 and 1789 from China to the North West Coast of America: With an Introductory Narrative of a Voyage Performed in 1786 from Bengal, in the Ship Nootka. 2 vols. London: Logographic Press. (Reprinted Da Capo NY 1967).

Miller, Robert

1999 Class lectures 4-1 to 5-27.

Mills, Bonnie and John Fagan's

1997 Letter to the Dept. of Natural Resources no. 157.

Minor et al

1980 "Cultural Resource Overview of the BLM Salem District NW Oregon: Archaeological, Ethnological, History". University of Oregon Anthropological Papers \#20, Eugene.

Minor, Rick

1984 "An Early Complex at the Mouth of the Columbia River". Northwest Anthropological Research Notes 18(1): 1-22. Moscow, Idaho.

1983 "Aboriginal Settlement and Subsistence at the Mouth of the Columbia River", (Unpublished Ph.D. Dissertation in Anthropology). Eugene:

University of Oregon.

Moore, John H.

1980 "Aboriginal Indian Settlement Patterns Preserved in Censuses and Allotments" Science 207:201-202.

Neihardt, John

1959 Black Elk Speaks. New York: Washington Square Press.

Newman, Thomas

1966 "Cascadia Cave" in Occasional Papers of the Idaho State University

No. 18 , Pocatello, Idaho.

Ortner, Sherry B. 
1994 "Theory in Anthropology Since the Sixties". In Culture, Power, History: A Reader in Contemporary Social Theory. Nicholas Dirks, Geoff Ely, Sherry Ortner eds. Princeton: Princeton University Press.

Palmer, Joel

1847 " Journal of travels over the Rocky Mountains to the mouth of the Columbia River; made during the Years 1845 and $1846 \ldots . "$

Cincinnati, Ohio: J.A. and U.P. James.

Pommersheim, Frank

1995 Braid of Feathers: American Indian Law and Contemporary Tribal Life. Berkeley: University of California Press.

Portlock, Nathaniel

1789 "A voyage Round the World; But More Particularly to the Northwest Coast of America: Performed 1785,1786,1787, and 1788, in the King George and Queen Charlotte" ... London: Printed for J.Stockdale, and G.Goulding. (Reprinted Da Capo press NY 1968).

Pettigrew, Richard

1975 "A Comparison of two Prehistoric Sites in Lane County, Oregon" in Archaeological Studies in the Willamette Valley, Oregon, C. Melvin Aikens ed. University of Oregon Anthropological Papers, no.8: 42454.

Quinn, William

1993 "Intertribal Integration: The Ethnological Argument in Duro v. Reina" Ethnohistory 40(1): 34-69.

Ramsey, Jarold ed.

1977 Coyote was going there: Indian Literature of the Oregon Country. Seattle: University of Washington Press.

Ray, Verne

1937 "The Historical Position of the Lower Chinook in the Native Culture of the Northwest". Pacific Northwest Quarterly 28(4): 363-372.

Riding In, James

1992 Without Ethics and Morality: A Historical Overview of Imperial Archaeology and American Indians "Arizona State Law Joumal" Spring. 
Ross, Alexander

1849 " Adventures of the first settlers on the Oregon or Columbia River: Being a Narrative of the Expedition fitted out by John Jacob Astor, to establish the pacific Fur Co. with an Account of Some Indian tribes on the Coast of the Pacific" London: Smith, Elder. (Reprinted Citadel Press, NY 1969)

1855 " The fur hunters of the far west" London: Smith, Elder (reprinted Donnelly and Sons: Chicago 1924

1956 [1977] " The fur hunters of the far west" Kenneth A. Spaulding, ed. Norman: University of Oklahoma Press.

Rucker, Maude

1930 "Jesse Applegate's Recollections of My Boyhood" in The Oregon Trail, New York: Walter McNeal. Pp 85-292.

Sapir, Edward

1909a Wishram Texts Publications of the American Ethnological Society 2 (Reprinted AMS Press 1974)

1909 Takelma Texts. University of Pennsylvania. University Museum. Anthropological Publications 2(1): 1-267. Philadelphia.

Schwartz, E.A.

1997 The Rogue River Indian War and its Aftermath,1850-1980. Norman: University of Oklahoma Press.

Scouler, John

1905 " Dr John Scouler's Journal of a Voyage to N.W. America [1824] F.G. Young, ed. Oregon Historical Quarterly 6(1) 54-75, (2) 159-205, (3) 276-287.

1841 " Observations on the Indigenous Tribes of the N.W. Coast of America. Journal of the Geographical Society of London 11:215-251.

1848 "On the Indian Tribes Inhabiting The Northwest Coast of America Journal of the Ethnological Society of London 1:0228-252.

Sider, Gerald

1994 "Identity as History: Ethnohistory, Ethnogenesis, and Ethnocide in the Southeastern United States" Identities 1(1): pp. 109-122.

1993 Lumbee Indian Histories: Race, Ethnicity, and Indian Identity in the Southern United States. New York: Cambridge University Press. 
Smith, Harriet

1976 "Wonderful Wapato: the Wild Potato" (Oregon Vignette) Lake

Oswego: Smith, Smith and Smith Publishing co.

1978 "Camas the Plant that Caused Wars" (An Oregon Vignette). Lake

Oswego: Smith, Smith and Smith Publishing co.

Silas Smith

1901 "Primitive Customs and Religious Beliefs of the Indians of the Pacific Northwest," in the Oregon Historical Quarterly \# 13.

Stepp, Davis

1994 "Descriptive Analysis of Human Remains From the Fuller and Fanning Mounds, Yamhill River, Willamette Valley, Oregon" (MA Thesis)

Eugene: Oregon State University.

Strickland, Rennard

1992 Implementing the National Policy of Understanding, Preserving, and Safeguarding the Heritage of Indian Peoples and Native Hawaiians.

"Arizona State Law Journal". Spring.

Strickland, Rennard

1975 Fire and the Spirits: Cherokee Law from Clan to Court. Norman:

University of Oklahoma Press.

Strong, Emory

1959 [1967] Stone Age on the Columbia River. Portland: Binfords and Mort.

Stuart, Robert

1935 The Discovery of the Oregon Trail: Robert Stuart's Narratives of his overland Trip Eastward from Astoria, 1812-1813. New York: Philip

A. Rollins, ed. Charles Scribner's Sons. (Translated)

Sturtevant, William

1983 "Tribe and State in the Sixteenth and Twentieth Centuries" in The

Development of Political Organization in Native North America: 1979 Proceedings of the American Ethnological Society. Elisabeth

Tooker ed. Washington D.C.: The American Ethological Society. Pp.3-16 
Sullivan, Maurice

1934 "Alexander McLeod's Journal" in The Travels of Jeddediah Smith. Santa Ana CA Fine Arts Press.

Summers, John

1877 Journals. At the Oregon Historical Society: Portland.

Suphan, Robert J.

1974 " An Ethnological Report on the Identity and Location of Certain Native Peoples of NW Oregon" in Oregon Indians I. New York: Garland Press.

Swanton, John

1952 (reprinted Smithsonian Institution Press 1968) "Indian Tribes of the North West" Bureau of American Ethnology Bulletin 145:

Washington.

Teit, James

1928 "The Middle Columbia Salish" Franz Boas ed. University of Washinton publications in Anthropology. 2(4): 83-128: Seattle.

Thwaites, Reuben

1904-1905 Original Journals of the Lewis and Clark Expedition, 1804-1806. 8 vols. New York: Dodd and Mead.

1904-1907 "Early Western Travels 1748-1846" 38 vols. Cleveland Ohio:

Arthur H Clark.

Tobie, H.E.

1927 "The Willamette Valley Before the Great Immigrations" (unpublished MA in Sociology). Eugene: University of Oregon.

Toepel, Kathryn

1985 The Flanagan Site: 6,000 Years of Occupation in the Upper Willamette Valley, Oregon. Ann Arbor: University Microfilms International.

Townsend, John

1978 " Narrative of a Journey across the Rocky Mountains To the Columbia River" [1839] Lincoln: University of Nebraska Press.

Underhill, Ruth 
1944 “Indians of the Pacific Northwest" (Sherman Pamphlets on Indian Life and Customs 5) Riverside Ca.: U.S. Office of Indian Affairs, Education division.

Vaughan, Champ Clark

1997 " Encounters with Molalla Indians, 1843 to 1906: Observations and Experiences of Early Oregon Pioneer William Hatchette Vaughan". Portland: Oregon Historical Institute.

Vaughn, Warren

1851 "Early History of Tillamook" Manuscript at the Oregon Historical Society.

Wilkinson, Charles

1987 American Indians, Time, and the Law. New Haven: Yale University

Press.

Wilson, Douglas

1998 Cultural Resource Survey of the Murphy Mill Site, Grand Ronde, Oregon. Archaeological Consulting report \#7.

Whitley, David

1994 "Shamanism, Natural Modeling and the Rock Art of Far Western North

American Hunter-Gathers" Shamanism and Rock Art in North

America, Solveig Turpin ed. Special Publication \#1, Rock Art

Foundation: San Antonio.

Zenk, Henry

1976 "Contribution to Tualatin Ethnography: Subsistence and Ethnobiology"

(unpublished MA thesis) Portland: Portland State University.

1984 "Chinook Jargon and Native Culture Persistence in the Grand Ronde

Community 1856-1907 as a Special Case of Colonization"

(Dissertation). Eugene: University of Oregon. 
Zucker et al

1983 Oregon Indians: Culture, History, and Cultural Affairs, An Atlas and Introduction. "Western Imprints." Portland: The Press of the Oregon Historical Society.

Documents

Annual Reports of the Superintendence [1859-1890]

The Applegate Transcripts [1901-1905]

Grand Ronde Original Rolls [1856?]

Grand Ronde Census [1872 and 1901]

Grand Ronde Allotment Records [1878]

Grand Ronde Legal Statutes [1876-1885]

Records of the Bureau of Indian Affairs, Grand Ronde, Record Group 75.

Press Copies of Letters from the Superintendency [1862-1920]

Letters to the Superintendent [1851-1925]

Records of Allotments or Inheritance.

\section{Maps}

Figure 1. from The United States In Old Maps and Prints. Washington :Atomium Books.

Figure 3. from Beckham, Steven Dow (1977) The Indians of West Oregon: This Land was Theirs. Coos Bay: Arago Books.

Figure 4. from Catholic Church Records of the Pacific Northwest: Grand Ronde. Vol 1 and 2. Munnick, Duncan Harriet and Steven Dow Beckham eds. Portland : Binford and Mort. 